Research Article

\title{
Effects of Lime, Vermicompost, and Chemical P Fertilizer on Selected Properties of Acid Soils of Ebantu District, Western Highlands of Ethiopia
}

\author{
Abdissa Bekele $\mathbb{D}^{1},{ }^{1}$ Kibebew Kibret, ${ }^{1}$ Bobe Bedadi, ${ }^{1}$ Markku Yli-Halla $\mathbb{D}^{2}{ }^{2}$ \\ and Tesfaye Balemi ${ }^{3}$ \\ ${ }^{1}$ School of Natural Resources Management and Environmental Sciences, Haramaya University, Dire Dawa, Ethiopia \\ ${ }^{2}$ Department of Food and Environmental Sciences, University of Helsinki, Helsinki, Finland \\ ${ }^{3}$ ILRI/CIMMYT, Gurd Shola, P.O. Box 5689, Addis Ababa, Ethiopia
}

Correspondence should be addressed to Abdissa Bekele; abdissabekele1@gmail.com

Received 10 November 2017; Revised 20 April 2018; Accepted 20 May 2018; Published 3 July 2018

Academic Editor: Teodoro M. Miano

Copyright ( $\odot 2018$ Abdissa Bekele et al. This is an open access article distributed under the Creative Commons Attribution License, which permits unrestricted use, distribution, and reproduction in any medium, provided the original work is properly cited.

\begin{abstract}
Soil acidity is one of the major factors limiting soil fertility and crop production in large areas of Ethiopia. A two-month incubation experiment was conducted to evaluate the effects of lime, vermicompost (VC), and chemical phosphorus (P) fertilizer on selected chemical properties of Dystric Nitisols in Ebantu District, Western Ethiopia. The treatments comprised of three rates of lime $\left(2,4\right.$, and 6 tons $\left.\mathrm{CaCO}_{3} \cdot \mathrm{ha}^{-1}\right)$, VC $\left(2.5,5\right.$, and 7.5 tons $\left.\cdot \mathrm{ha}^{-1}\right)$, and mineral P fertilizer $\left(20,40\right.$, and $\left.60 \mathrm{~kg} \cdot \mathrm{P} \cdot \mathrm{ha} \mathrm{a}^{-1}\right)$ each applied alone and in various combinations. The experiment was laid down in a completely randomized design with two replications. The results showed that the highest increment of $\mathrm{pH}$ from 4.83 at the control to 6.05 and reduction of exchangeable $\mathrm{Al}$ from 1.70 to $0.09 \mathrm{cmol}_{\mathrm{c}} \cdot \mathrm{kg}^{-1}$ were obtained from combined application of lime at 4 tons $\mathrm{CaCO}_{3} \cdot \mathrm{ha}^{-1}$ and VC at 7.5 tons $\cdot \mathrm{ha}^{-1}$. The most significant decrease in exchangeable acidity $\left(0.17 \mathrm{cmol}_{\mathrm{c}} \cdot \mathrm{kg}^{-1}\right)$ was observed in soil that was treated with 6 tons $\mathrm{CaCO}_{3} \cdot \mathrm{ha}^{-1}$ lime applied alone (93\%) and combined application of lime at 4 tons $\mathrm{CaCO}_{3} \cdot \mathrm{ha}^{-1}$ with $\mathrm{VC}$ at 7.5 tons.ha ${ }^{-1}$ by (81\%). The highest contents of OM (4.1\%) and total nitrogen $(0.29 \%)$ were obtained from combined application of lime at 4 tons $\mathrm{CaCO}_{3} \cdot \mathrm{ha}^{-1}$ and VC at 7.5 tons $\cdot \mathrm{ha}^{-1}$. Integrated application of chemical P $\left(60 \mathrm{~kg} \cdot \mathrm{P} \cdot \mathrm{ha}^{-1}\right)$ with lime $\left(2\right.$ tons $\left.\cdot \mathrm{ha}^{-1}\right)$ plus VC $\left(7.5\right.$ tons $\left.\cdot \mathrm{ha}^{-1}\right)$ resulted in Bray-II P increased by $45 \%$ relative to control. The various combinations of the treatments also improved exchangeable $\mathrm{Ca}^{2+}$ and $\mathrm{Mg}^{2+}$. The results indicate that integrated use of lime, vermicompost, and chemical $\mathrm{P}$ fertilizer can improve soil acidity and availability of nutrients. However, the real potential of the amendments used in this experiment should be further assessed under field conditions using a test crop.
\end{abstract}

\section{Introduction}

Soil acidity is a widespread limitation to crop production in many parts of the world [1]. It is a major constraint to agricultural productivity throughout Africa where high rainfall is common due to the deficiencies of nitrogen $(\mathrm{N})$ by leaching, phosphorus $(\mathrm{P})$ by fixation, and low soil organic matter (OM) [2-4]. As indicated by Schlede [5], World Bank [6], and Wassie and Shiferaw [7], acidic soils cover a significant part of soils of Ethiopia. Hence, it is a serious threat to crop production in most highlands and a major crop production constraint in the small-scale farmers of the country. Specifically because of the severity of soil acidity problem, many crops give a very low productivity in the study district.

Based on the problem that soil acidity causes on a larger areas in Ethiopia, it needs due attention to be addressed by different coping mechanisms [8]. The productivity of crops in acid soils with $\mathrm{Al}$ toxicity and low soil availability of $\mathrm{P}$ may be improved by use of lime, fertilizers with liming effects, and/or organic materials $[9,10]$. Lime is the most effective means of amending soil acidity $[2,11]$. Application of lime containing $\mathrm{Ca}$ and/or $\mathrm{Mg}$ compounds to acid soil increases $\mathrm{Ca}^{2+}$ and/or $\mathrm{Mg}^{2+}$ ions and reduces $\mathrm{Al}^{3+}, \mathrm{H}^{+}, \mathrm{Mn}^{2+}$, and $\mathrm{Fe}^{2+}$ 
ions in the soil solution. Hence, this leads to increased soil $\mathrm{pH}$ and available $\mathrm{P}$ due to reduction in $\mathrm{P}$ sorption $[1,3]$. Increasing soil $\mathrm{pH}$ liming makes other nutrients more available and prevents $\mathrm{Al}$ and $\mathrm{Mn}$ from being toxic to plant growth [12]. Liming also enhances root development and water and nutrient uptakes necessary for healthy plant growth [1, 11].

The Ethiopian soils, similar to the other agricultural soils of the tropics, are generally low in $\mathrm{P}[13,14]$, and hence, $\mathrm{P}$ is one of the limiting elements in crop production in the highlands of Ethiopia. Use of mineral P fertilizers increases the soil available $\mathrm{P}$ in $\mathrm{P}$-deficient tropical acid soils $[11,15]$. Melese et al. [16] also suggested that application of the mineral $\mathrm{P}$ fertilizer with other amendments can be used to improve P deficiency in acid soils. Even though the chemical fertilizers including mineral $\mathrm{P}$ are used to increase productivity for a certain time, their negative impacts coupled with their high cost have prompted the interest in the use of organic fertilizers as source of nutrients.

Organic fertilizer application has been reported to improve crop growth by supplying plant nutrients as well as improving soil physical, chemical, and biological properties [17]. Vermicompost (VC) is one of the stabilized, finely divided organic fertilizers with a low $\mathrm{C}$ : $\mathrm{N}$ ratio, high porosity, and high water-holding capacity, in which most nutrients are present in forms that are readily available for plants [18, 19]. There is an increasing interest in the potential use of $\mathrm{VC}$ as soil amendment [20-22]. Application of VC showed marked improvements in the overall physical and biochemical properties, and at the same time, VC decreases exchangeable acidity which can support a release of plant nutrients in the acidic soils [23]. Current trends in agriculture are centered on reducing the use of inorganic fertilizers by biofertilizers such as VC [24]. There is good evidence that VC application promotes growth of plants and positive effect on growth and productivity of cereals and legumes $[20,25,26]$. When it is compared with conventional compost, VC promotes growth from 50 to $100 \%$ over conventional compost and from 30 to $40 \%$ over chemical fertilizers [27].

The combined application of inorganic and organic fertilizers is widely recognized as a way of improving productivity of the soil sustainably [28]. Several researchers [28-31] have demonstrated the beneficial effect of integrated nutrient management in mitigating the deficiency of several macro- and micronutrients.

Many parts of the Ethiopian highlands have a problem of acidity which causes the gradual reduction of soil fertility and crop productivity. Almost no research has been done on the effect of VC individually and combined with lime and inorganic fertilizers in ameliorating the acidic soils of the country in general and the study area in particular, except few studies conducted on amendments of acidic soils by lime and lime with other organic and inorganic fertilizers other than VC in different areas [16, 32-34].

Yet, most researches just focus on the effect of different ameliorating material on soil acidity. Indeed, no work has been done in ameliorating acidic soils and improving nutrient deficiency by the individual and combined applications of lime, VC, and mineral P. Therefore, the objective of this study was to evaluate the effects of lime, VC, and mineral $P$ fertilizers in ameliorating soil acidity-related problems and other selected chemical properties on acidic soils of Ebantu District, Western highlands of Ethiopia.

\section{Materials and Methods}

\subsection{Description of the Study Area and Sample Collection.} The study was conducted in Ebantu District, East Wollega Zone of Oromia National Regional State (ONRS) (Figure 1). It is located in the western part of Ethiopia at approximately $483 \mathrm{~km}$ from Addis Ababa and around $153 \mathrm{~km}$ from Nekemte, the capital city of East Wollega zone. The district lies between $9^{\circ} 58^{\prime} 30^{\prime \prime}$ to $10^{\circ} 14^{\prime} 0^{\prime \prime} \mathrm{N}$ latitude and $36^{\circ} 3^{\prime} 0^{\prime \prime}$ to $36^{\circ} 29^{\prime} 0^{\prime \prime}$ E longitude and covers an estimated area of $929 \mathrm{~km}^{2}$ with an altitude that ranges from 1994 to 2176 meters above sea level (masl).

Geologically, the study area is covered by the metamorphic basement rocks in which tertiary volcanic rocks buildup and that is characterized by fine granular rock, small crystal which is invisible by necked eye. This rock is characterized by large vesicles from where gas escaped out and used for percolation of precipitation [35]. The predominant soil type in southwest and western Ethiopia in general and the study area in particular is Dystric Nitisols according to [36] the soil classification system. Its vernacular name is "Biyyee Diimaa" meaning red soil. On the average, the soil is deep and relatively highly weathered, well drained, and very strongly to strongly acidic in reaction. Nitisols are highly weathered soils in the warm and humid areas of the west and southwest Ethiopia [37].

In terms of topography, $30 \%$ of the total area is gentle slope, while flat and steep slope lands account for 52 and $18 \%$, respectively. Out of the total area of the district, $35 \%$ is covered by cultivated land, $19 \%$ by grazing land, $20 \%$ by natural forest land, $16 \%$ by fallow land, and $8 \%$ by shrubs, and about $2 \%$ is estimated to be area covered by settlement (Ebantu District Agricultural development Bureau, 2014 unpublished). The natural forest in the study area consists of some tree species that are remnants of a once dense evergreen forest occurring in various areas of the district. The dominant tree species in the area include Acacia etbaica, Acacia abyssinica, Cordia africana, Syzygium guineense, Ficus sur, Albizia julibrissin, Eucalyptus sp., Croton macrostachyus, and Podocarpus falcatus (personal observation).

According to the local and the Ethiopian agroclimatic zonation [38], the study area belongs to the humid (Baddaa) and subhumid (Badda Daree) climatic zones. The economic activities of the local society of the study area are primarily mixed farming system that involves animal husbandry and crop production. Continuous cultivation without any fallow periods coupled with complete removal of crop residues is a common practice on cultivated fields. Farmers in the study area use diammonium phosphate (DAP), urea, and cow dung as sources of fertilizers. The major crops are maize (Zea mays L.), teff (Eragrostis tef), coffee (Coffee arabica L.), barley (Hordeum vulgare L.), potato (Solanum tuberosum L.), and noug (Guizotia abyssinica). These major crops are produced usually once per year. 


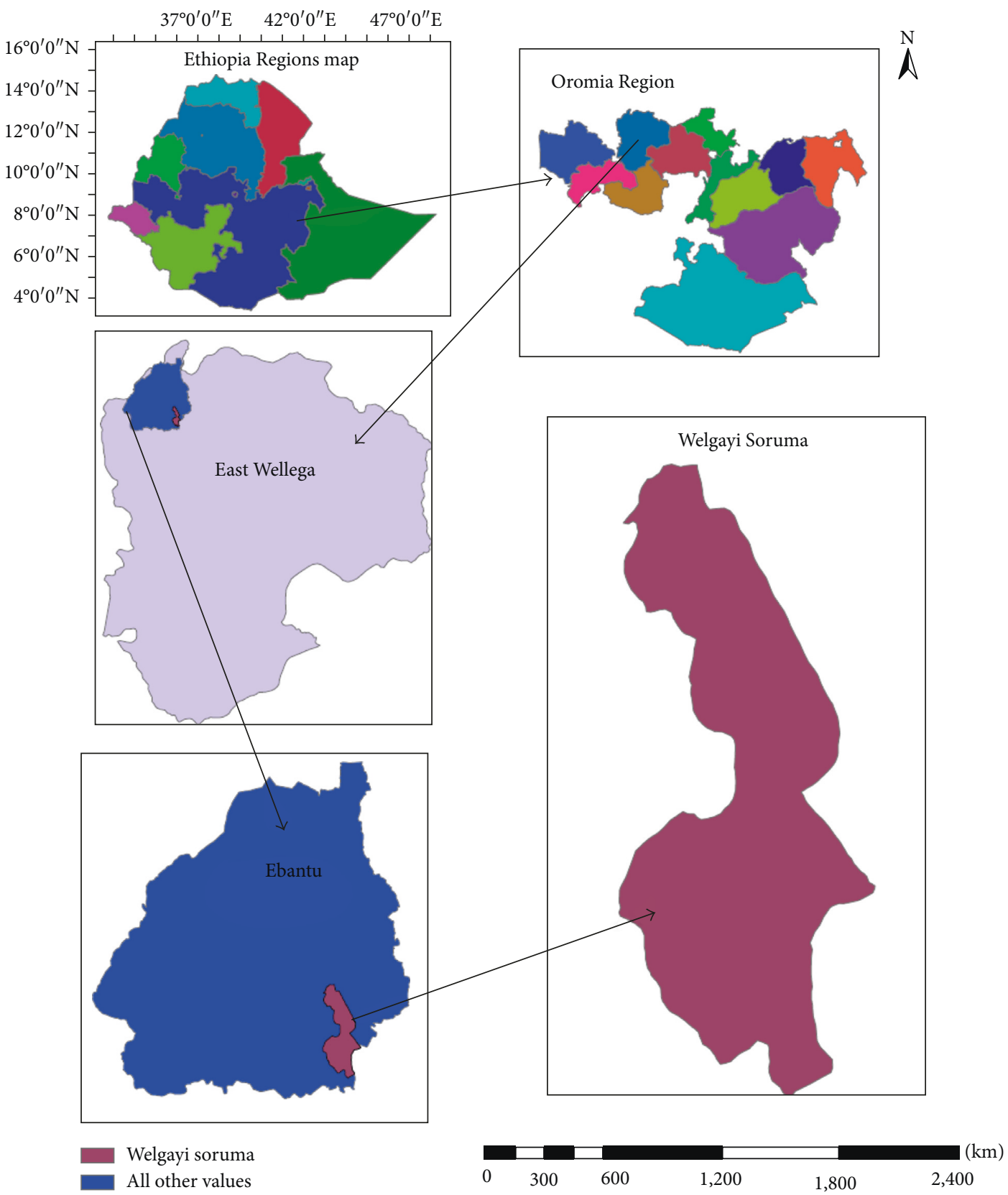

Figure 1: Location map of Ethiopia regions (a) and Oromia National Regional State (ONRS) (b).

The district receives an annual average rainfall of $1778 \mathrm{~mm}$ and has monthly mean minimum, maximum, and mean air temperatures of $16.6,20$, and $18.3^{\circ} \mathrm{C}$, respectively [39] (Figure 2). The rainfall pattern is unimodal, stretching from April to October.

A bulk soil sample was taken from the surface soil (0$20 \mathrm{~cm}$ ) from the very strongly acidic soil of the Walgayi Soruma sampling site in Ebantu District, Western Highlands of Ethiopia. Totally, three composite samples were collected from the three blocks. Soil samples were collected by auger from eighteen subsamples in each block and thoroughly mixed to make a composite. The soil was air-dried, ground, and passed through a $2 \mathrm{~mm}$ and $0.5 \mathrm{~mm}$ sieve and analyzed for selected soil physicochemical properties. At the same time, a total of 3 undisturbed soil samples at $0-20 \mathrm{~cm}$ depth layer to determine soil bulk density $(\mathrm{BD})$ of the area were collected in random by taking one sample per block using the core method. All the laboratory activities were undertaken at Haramaya University and the Nekemte Soil Research Center.

2.2. Set Up of the Incubation Experiment. The incubation experiment was conducted for two months as described below. The composite soil sample with three replicates was air-dried, ground, and passed with $2 \mathrm{~mm}$ sieve, and then $0.3 \mathrm{~kg}$ soil was placed in plastic pot and mixed with different treatments in a greenhouse. During incubation, soil 


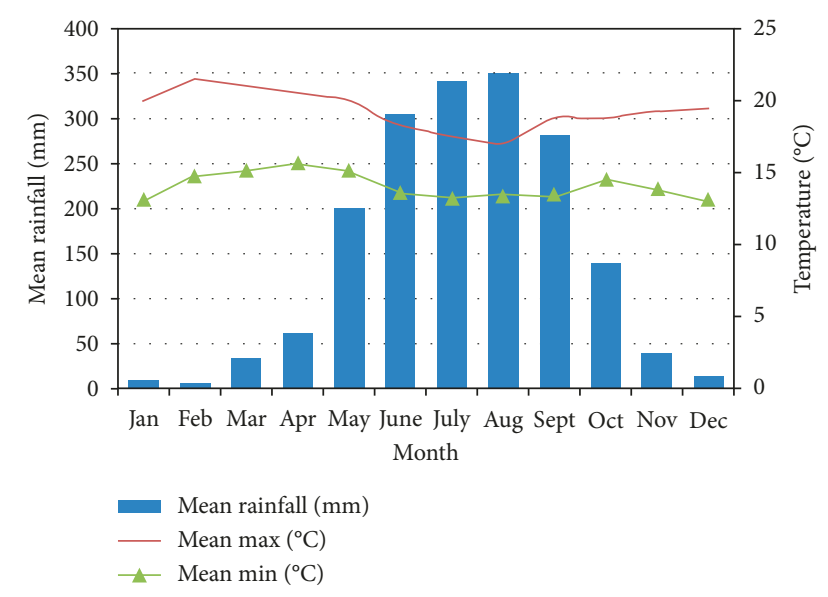

FIGURE 2: Mean monthly rainfall (mm), minimum, and maximum temperatures $\left({ }^{\circ} \mathrm{C}\right)$ of the study area recorded for the year from 2006 to 2015. Source: National Meteorological Agency; Gida Ayana Meteorological Station.

moisture was adjusted to a constant weight $60 \%$ (field capacity) with distilled water at the end of every 3 -day period.

In this experiment, lime $\left(\mathrm{CaCO}_{3}\right)$ at rates of 2,4 , and 6 tons $\cdot \mathrm{ha}^{-1}$ (corresponding with $0.231,0.462$, and $0.693 \mathrm{~g} /$ $0.3 \mathrm{~kg}$ soil, resp.), based on the results from LR tests to reach desired $\mathrm{pH}$ values, three $\mathrm{VC}$ rates $\left(2.5,5\right.$ and 7.5 tons.ha $\left.{ }^{-1}\right)$, and three mineral P fertilizer rates $\left(20,40\right.$, and $\left.60 \mathrm{~kg} \cdot \mathrm{P} \cdot \mathrm{ha} \mathrm{a}^{-1}\right)$, as triple superphosphate $\left(\mathrm{Ca}\left(\mathrm{H}_{2} \mathrm{PO}_{4}\right)_{2}\right)$, were separately applied uniformly to the whole soil volume. The lime rate (4 tons $\cdot \mathrm{ha}^{-1}$ ) was combined separately with each of VC and mineral $\mathrm{P}$ fertilizer rates as treatments, $\mathrm{VC}$ rate $\left(5\right.$ tons $\left.\cdot \mathrm{ha}^{-1}\right)$ was combined separately with each of mineral $\mathrm{P}$ fertilizer rate and different rates of lime, and VC and mineral $\mathrm{P}$ were combined and applied to the soil as additional five treatments. A control treatment with no soil amendments was used for the incubation experiment. A total of 48 pots were used for the incubation experiment. The experiment was laid down in a completely randomized design (CRD) with two replications. The units of the treatments were converted into hectare bases by assuming that the plough depth is $20 \mathrm{~cm}$ and $\rho_{\mathrm{b}}$ of the soil is $1.3 \mathrm{~g} \cdot \mathrm{cm}^{-3}$. The soils were incubated with the treatments in the pots for two months (November and December, 2014) at Haramaya University main campus (rare).

Soil samples were taken at the end of the incubation time, air-dried, ground, and sieved through $2 \mathrm{~mm}$ and $0.5 \mathrm{~mm}$ sieve to observe the effects of lime, VC and mineral P individually and in combined form on selected soil acidity related and other soil chemical properties at Haramaya University central and soil chemistry laboratory.

2.3. Soil Analyses. Soil particle size distribution was analyzed by the Bouyoucus hydrometer method [40] after the soil samples were dispersed with sodium hexametaphosphate $\left[\left(\mathrm{NaPO}_{3}\right)_{6}\right]$. Soil bulk density $\left(\rho_{\mathrm{b}}\right)$ was measured from three undisturbed soil samples collected using a core sampler $(2.5 \mathrm{~cm}$ radius and $5.0 \mathrm{~cm}$ height $)$ as per the procedure described by Jamison et al. [41] while particle density $\left(\rho_{\mathrm{s}}\right)$ was measured using the pycnometer [42] at the Nekemte Soil
Research Center. Total porosity $(\varphi)$ was calculated from the values of $\rho_{\mathrm{b}}$ and $\rho_{\mathrm{s}}$ as follows:

$$
\varphi=\left(1-\frac{\rho_{\mathrm{b}}}{\rho_{\mathrm{s}}}\right) * 100
$$

Soil $\mathrm{pH}$ was measured potentiometrically in $1: 2.5$ soil: $\mathrm{H}_{2} \mathrm{O}$ suspension using a combined glass electrode $\mathrm{pH}$ meter [43]. Total exchangeable acidity was determined by saturating the soil samples with $1 \mathrm{M} \cdot \mathrm{KCl}$ suspension as described by [44]. From the same extract, exchangeable $\mathrm{Al}$ in the soil samples was determined by application of $1 \mathrm{M} \cdot \mathrm{NaF}$ which forms a complex with $\mathrm{Al}$ and releases $\mathrm{NaOH}$. Acid saturation (AS) was calculated as follows:

$$
\text { AS }(\%)=\frac{\text { exchangeable acidity }\left(\mathrm{cmol}_{\mathrm{c}} \cdot \mathrm{kg}^{-1}\right)}{\operatorname{ECEC~}\left(\mathrm{cmol}_{\mathrm{c}} \cdot \mathrm{kg}^{-1}\right)} \times 100 \text {, }
$$

where AS refers to acid saturation and ECEC refers to effective cation exchange capacity.

Organic carbon (OC) content of the soil was determined by the wet combustion procedure of Walkley and Black [45]. Organic matter was determined by multiplying OC by 1.724 factors. The total nitrogen $(\mathrm{N})$ content of the soil was determined by wet-oxidation procedure of the Kjeldahl method [46]. Available P was extracted by the Bray-II method [47] using $0.03 \mathrm{M} \cdot \mathrm{NH}_{4} \mathrm{~F}$ and $0.1 \mathrm{M} \cdot \mathrm{HCl}$ solution.

Exchangeable basic cations $(\mathrm{Ca}, \mathrm{Mg}, \mathrm{K}$ and $\mathrm{Na}$ ) were determined by saturating several times the soil samples with $1 \mathrm{M} \cdot \mathrm{NH}_{4} \mathrm{OAc}$ solution at $\mathrm{pH}$ 7.0. Then $\mathrm{Ca}$ and $\mathrm{Mg}$ were determined by using atomic absorption spectrophotometry (AAS), while exchangeable $\mathrm{Na}$ and $\mathrm{K}$ were measured by flame photometer from the same extract [48]. The effective cation exchange capacity (ECEC) was calculated as the sum of exchangeable acidity $\left(\mathrm{Al}^{3+}\right.$ and $\mathrm{H}^{+}$) and exchangeable basic cations $\left(\mathrm{Ca}^{2+}, \mathrm{Mg}^{2+}, \mathrm{K}^{+}\right.$, and $\left.\mathrm{Na}^{+}\right)$[49].

The extractable micronutrients $(\mathrm{Fe}, \mathrm{Mn}, \mathrm{Zn}$, and $\mathrm{Cu})$ were extracted by diethylene triamine pentaacetic acid (DTPA), and all these micronutrients were measured by AAS [50].

2.4. Vermicompost and Lime Analyses. The VC was prepared from decomposition of cow dung, sheep and goat manures, crop and home residues, and weeds and grasses by using red earthworm (Eisenia fetida). Selected parameters of VC were determined using dried samples which were ground to pass through a $2 \mathrm{~mm}$ sieve as described by Pisa and Wuta [51]. Electrical conductivity (EC) and $\mathrm{pH}$ were determined from a suspension of $1: 10 \mathrm{VC}: \mathrm{H}_{2} \mathrm{O}$ as described by Ndegwa and Thompson [52]. The total OC was estimated by the wet digestion and rapid titration method [45]. The total $\mathrm{N}$ content of the VC was determined by wet-oxidation procedure of the Kjeldahl method [46]. Total $\mathrm{Ca}, \mathrm{Mg}$, K, and $\mathrm{Na}$ were extracted by wet digestion using concentrated sulphuric acid $\left(\mathrm{H}_{2} \mathrm{SO}_{4}\right)$, selenium ( $\mathrm{Se}$ ) powder, lithium sulphate $\left(\mathrm{Li}_{2} \mathrm{SO}_{4}\right)$, and hydrogen peroxide $\left(\mathrm{H}_{2} \mathrm{O}_{2}\right)$ mixture [53]. Total $\mathrm{Ca}$ and $\mathrm{Mg}$ were determined from the wet digested samples by AAS while $\mathrm{K}$ and $\mathrm{Na}$ were estimated by flame photometer. Total $\mathrm{P}$ was extracted using concentrated $\mathrm{H}_{2} \mathrm{SO}_{4}$, Se 
powder, salicylic acid $\left(\mathrm{C}_{7} \mathrm{H}_{6} \mathrm{O}_{3}\right)$, and $\mathrm{H}_{2} \mathrm{O}_{2}$ mixture [53]. Total micronutrients $(\mathrm{Fe}, \mathrm{Mn}, \mathrm{Zn}$, and $\mathrm{Cu}$ ) were extracted using concentrated $\mathrm{H}_{2} \mathrm{SO}_{4}$, Se powder, $\mathrm{C}_{7} \mathrm{H}_{6} \mathrm{O}_{3}$, and $\mathrm{H}_{2} \mathrm{O}_{2}$ mixture, and their concentrations were determined from the wet digested samples by AAS [53].

The calcium carbonate equivalent (CCE) of the Guder lime was determined by dissolving the lime using excess of standard $0.5 \mathrm{M} \cdot \mathrm{HCl}$ and followed by gentle boiling. After filtration, the excess $\mathrm{HCl}$ was back titrated with standard $0.1 \mathrm{M} \cdot \mathrm{NaOH}$ solution. From the amount of $\mathrm{NaOH}$ used to neutralize the excess acid of the blank and the filtrate, the CCE value of the lime was calculated [50].

Lime requirement was determined by the acid saturation method to ameliorate the acidic soil of the study site for the maize crop. The acid saturation method uses exchangeable acidity, ECEC, and permissible acid saturation percentage of crops to calculate the amount of lime to be applied. Using the acid saturation method, lime requirement is calculated as follows [54]:

$$
\text { LR }\left(\mathrm{kg} \cdot \mathrm{ha}^{-1}\right)=\operatorname{LRF}[\text { Ex. acidity }-(\text { ECEC } * \text { PAS })],
$$

where $\mathrm{LR}=$ lime requirement, $\mathrm{LRF}=$ lime requirement factor $\left(\mathrm{kg} \cdot \mathrm{lime} \cdot \mathrm{ha}^{-1}\right)$ to lower the Ex. acidity by $1 \mathrm{cmol}$ (3000 kg lime $/ \mathrm{ha} / \mathrm{cmole})$ [55] for most Ethiopian soils, Ex. acidity $=$ exchangeable acidity $\left(\mathrm{Al}^{3+}+\mathrm{H}^{+}\right)$, PAS $=$permissible acid saturation, and ECEC = effective cation exchange capacity (exchangeable acidity + exchangeable bases).

2.5. Statistical Analysis. Analysis of variance was carried out on the effect of treatments on selected soil chemical properties using SAS software [56]. Duncan's multiple range test was employed to test the significance difference between means of treatments. Simple Pearson correlation analysis was executed to determine the associations between various soil acidity parameters and different soil chemical properties.

\section{Results and Discussion}

3.1. Initial Soil Properties and Vermicompost Composition. The results of laboratory analysis of selected properties of the soil used for the experiment are presented in Table 1. The textural class of the soil used for the incubation experiment is loam. The bulk density of the soil was below the critical value of bulk density $\left(1.6 \mathrm{gcm}^{-3}\right)$ for plant growth at which root penetration is likely to be severely restricted in a loam soil [57], while the particle density is lower than the average particle density value for a mineral soil. Due to the low bulk density value, the total porosity of the soil was relatively high. The soil was strongly acidic [57] with relatively high content of exchangeable acidity and Al. The percentage acid saturation of the soil was $30.7 \%$. The organic matter and total nitrogen contents of the soil were in the range of low and moderate, respectively [58], while the available $\mathrm{P}$ content was in the low range [59]. Similarly, the mean soil exchangeable $\mathrm{Ca}$ and $\mathrm{K}$ were low, whereas exchangeable $\mathrm{Mg}$ was within the range of medium [60]. The effective CEC of the soils was also relatively low probably due to the dominance of low activity clay minerals in the highly weathered
TABLE 1: Selected physical and chemical properties of the experimental soil before incubation.

\begin{tabular}{|c|c|}
\hline Parameters & Value \\
\hline Sand (\%) & 50.0 \\
\hline Silt (\%) & 38.0 \\
\hline Clay $(\%)$ & 12.0 \\
\hline Textural class & Loam \\
\hline $\mathrm{BD}\left(\mathrm{g} \cdot \mathrm{cm}^{-3}\right)$ & 1.30 \\
\hline PD $\left(\mathrm{g} \cdot \mathrm{cm}^{-3}\right)$ & 2.28 \\
\hline $\mathrm{TP}(\%)$ & 43.00 \\
\hline $\mathrm{pH}\left(\mathrm{H}_{2} \mathrm{O}\right)$ & 4.80 \\
\hline Exchangeable acidity $\left(\mathrm{cmol}_{\mathrm{c}} \cdot \mathrm{kg}^{-1}\right)$ & 2.44 \\
\hline Exchangeable $\mathrm{Al}\left(\mathrm{cmol}_{\mathrm{c}} \cdot \mathrm{kg}^{-1}\right)$ & 2.03 \\
\hline AS $(\%)$ & 30.70 \\
\hline OM (\%) & 2.15 \\
\hline Total N (\%) & 0.18 \\
\hline Available P by Bray-II (mg.kg ${ }^{-1}$ ) & 4.60 \\
\hline Exchangeable $\mathrm{Ca}\left(\mathrm{cmol}_{\mathrm{c}} \cdot \mathrm{kg}^{-1}\right)$ & 3.51 \\
\hline Exchangeable $\mathrm{Mg}\left(\mathrm{cmol}_{\mathrm{c}} \cdot \mathrm{kg}^{-1}\right)$ & 1.61 \\
\hline Exchangeable $\mathrm{K}\left(\mathrm{cmol}_{\mathrm{c}} \cdot \mathrm{kg}^{-1}\right)$ & 0.27 \\
\hline Exchangeable $\mathrm{Na}\left(\mathrm{cmol}_{\mathrm{c}} \cdot \mathrm{kg}^{-1}\right)$ & 0.11 \\
\hline $\operatorname{ECEC~}\left(\mathrm{cmol}_{\mathrm{c}} \cdot \mathrm{kg}^{-1}\right)$ & 7.94 \\
\hline $\mathrm{Fe}\left(\mathrm{mg} \cdot \mathrm{kg}^{-1}\right)$ & 35.10 \\
\hline $\mathrm{Mn}\left(\mathrm{mg} \cdot \mathrm{kg}^{-1}\right)$ & 36.70 \\
\hline $\mathrm{Zn}\left(\mathrm{mg} \cdot \mathrm{kg}^{-1}\right)$ & 2.96 \\
\hline $\mathrm{Cu}\left(\mathrm{mg} \cdot \mathrm{kg}^{-1}\right)$ & 2.73 \\
\hline
\end{tabular}

$\mathrm{BD}$, bulk density; PD, particle density; TP, total porosity; AS, acid saturation; $\mathrm{OM}$, organic matter; total $\mathrm{N}$, total nitrogen; ECEC, effective cation exchange capacity.

TABLE 2: Chemical characterization of vermicompost.

\begin{tabular}{lc}
\hline Vermicompost & Value \\
\hline $\mathrm{pH}\left(\mathrm{H}_{2} \mathrm{O}\right)(1: 10)$ & 7.5 \\
$\mathrm{EC}\left(\mathrm{dSm}^{-1}\right)(1: 10)$ & 5.2 \\
Total OC $(\%)$ & 14.3 \\
Total N $(\%)$ & 1.95 \\
Total P $\left(\mathrm{g}^{\mathrm{kg}} \mathrm{kg}^{-1}\right)$ & 5.3 \\
$\mathrm{Ca}\left(\mathrm{cmol}_{\mathrm{c}} \cdot \mathrm{kg}^{-1}\right)$ & 36.3 \\
$\mathrm{Mg}\left(\mathrm{cmol}_{\mathrm{c}} \cdot \mathrm{kg}^{-1}\right)$ & 19.8 \\
$\mathrm{~K}\left(\mathrm{cmol}_{\mathrm{c}} \cdot \mathrm{kg}^{-1}\right)$ & 27.7 \\
$\mathrm{Na}\left(\mathrm{cmol}_{\mathrm{c}} \cdot \mathrm{kg}^{-1}\right)$ & 14.2 \\
$\mathrm{Fe}\left(\mathrm{mg}^{-1} \mathrm{~kg}^{-1}\right)$ & 219.0 \\
$\mathrm{Mn}\left(\mathrm{mg}_{\mathrm{kg}} \mathrm{kg}^{-1}\right)$ & 397.0 \\
$\mathrm{Zn}\left(\mathrm{mg} \cdot \mathrm{kg}^{-1}\right)$ & 152.0 \\
$\mathrm{Cu}\left(\mathrm{mg} \cdot \mathrm{kg}^{-1}\right)$ & 95.0 \\
\hline
\end{tabular}

EC, electrical conductivity; total OC, total organic carbon; total N, total nitrogen; total $\mathrm{P}$, total phosphorus.

soils of the study area. As per rating suggested by Jones [57], the soil was high in DTPA-extractable Fe, Mn, and $\mathrm{Zn}$ and medium in extractable $\mathrm{Cu}$ [57]. In general, the results of the soil preanalysis clearly indicate that the soil has soil fertility problems that include deficiency of major plant nutrients and soil acidity that limit successful production of crops in the study area. This calls for development of appropriate management practices that enhance crop production on a sustainable basis.

The lime used in this study had CCE value of $88.7 \%$. Table 2 shows the nutrient contents of the vermicompost used for the experiment. The nutrients are likely to be 
TABLE 3: Effects of the treatments on $\mathrm{pH}$, exchangeable acidity and exchangeable $\mathrm{Al}$, and percent acid saturation of soil in the incubation study.

\begin{tabular}{|c|c|c|c|c|c|}
\hline Treatment & Rate & $\mathrm{pH}$ & \multicolumn{2}{|c|}{$\mathrm{cmol}_{\mathrm{c}} \cdot \mathrm{kg}^{-1}$} & $\begin{array}{c}\text { AS } \\
\%\end{array}$ \\
\hline \multirow[t]{2}{*}{ Control } & 0 & $4.83^{j}$ & $2.38^{\mathrm{a}}$ & $1.70^{\mathrm{a}}$ & $30^{\mathrm{a}}$ \\
\hline & 2 & $5.20^{\mathrm{f}-\mathrm{i}}$ & $2.13^{b c}$ & $1.28^{\mathrm{C}}$ & $23^{c}$ \\
\hline \multirow[t]{3}{*}{ Lime (tons $\cdot \mathrm{ha}^{-1}$ ) } & 4 & $5.44^{\mathrm{c}-\mathrm{f}}$ & $1.15^{\mathrm{gh}}$ & $1.12^{\mathrm{e}}$ & $12^{\mathrm{g}}$ \\
\hline & 6 & $6.01^{\mathrm{a}}$ & $0.17^{1}$ & $0.33^{\mathrm{j}}$ & $1.62^{j}$ \\
\hline & 20 & $5.17^{\text {ghi }}$ & $2.36^{\mathrm{a}}$ & $1.70^{\mathrm{a}}$ & $27^{\mathrm{b}}$ \\
\hline \multirow[t]{3}{*}{ Mineral P $\left(\mathrm{kg} \cdot \mathrm{ha}^{-1}\right)$} & 40 & $4.97^{\text {hij }}$ & $2.34^{\mathrm{a}}$ & $1.71^{\mathrm{a}}$ & $30^{\mathrm{a}}$ \\
\hline & 60 & $4.95^{\mathrm{ij}}$ & $2.38^{\mathrm{a}}$ & $1.71^{\mathrm{a}}$ & $30^{\mathrm{a}}$ \\
\hline & 2.5 & $5.18^{\mathrm{ghi}}$ & $2.18^{\mathrm{b}}$ & $1.63^{\mathrm{b}}$ & $20^{\mathrm{d}}$ \\
\hline \multirow[t]{3}{*}{$\mathrm{VC}\left(\right.$ tons $\cdot \mathrm{ha}^{-1}$ ) } & 5.0 & $5.19^{\mathrm{f}-\mathrm{i}}$ & $2.05^{\mathrm{cd}}$ & $1.57^{\mathrm{b}}$ & $17^{\mathrm{e}}$ \\
\hline & 7.5 & $5.46^{\text {cde }}$ & $1.99^{\mathrm{d}}$ & $1.31^{\mathrm{c}}$ & $16^{\mathrm{ef}}$ \\
\hline & 20 & $5.47^{\text {cde }}$ & $1.18^{\mathrm{g}}$ & $1.14^{\mathrm{e}}$ & $12^{\mathrm{g}}$ \\
\hline \multirow[t]{3}{*}{ Chemical P $\left(\mathrm{kg} \cdot \mathrm{ha}^{-1}\right)+$ lime $\left(4\right.$ tons $\left.\cdot \mathrm{ha}^{-1}\right)$} & 40 & $5.48^{\text {cde }}$ & $1.16^{\mathrm{g}}$ & $1.14^{\mathrm{e}}$ & $12^{\mathrm{g}}$ \\
\hline & 60 & $5.52^{\mathrm{cd}}$ & $1.13^{\text {ghi }}$ & $1.10^{\mathrm{ef}}$ & $12^{\mathrm{g}}$ \\
\hline & 2.5 & $5.62^{\mathrm{bc}}$ & $1.11^{\mathrm{ghi}}$ & $1.04^{\mathrm{fg}}$ & $9^{h}$ \\
\hline \multirow[t]{3}{*}{$\mathrm{VC}\left(\right.$ tons $\left.\cdot \mathrm{ha}^{-1}\right)+$ lime $\left(4\right.$ tons $\left.\cdot \mathrm{ha}^{-1}\right)$} & 5.0 & $5.98^{\mathrm{a}}$ & $1.00^{\mathrm{j}}$ & $0.80^{\mathrm{i}}$ & $8^{\mathrm{h}}$ \\
\hline & 7.5 & $6.05^{\mathrm{a}}$ & $0.45^{\mathrm{k}}$ & $0.09^{\mathrm{k}}$ & $3.3^{\mathrm{i}}$ \\
\hline & 20 & $5.24^{\mathrm{efg}}$ & $2.04^{\mathrm{d}}$ & $1.59^{\mathrm{b}}$ & $17^{\mathrm{e}}$ \\
\hline \multirow{2}{*}{ Chemical P $\left(\mathrm{kg} \cdot \mathrm{ha}^{-1}\right)+\mathrm{VC}\left(5\right.$ tons $\left.\cdot \mathrm{ha}^{-1}\right)$} & 40 & $5.23^{\mathrm{e}-\mathrm{h}}$ & $2.07^{\mathrm{cd}}$ & $1.57^{\mathrm{b}}$ & $17^{\mathrm{e}}$ \\
\hline & 60 & $5.67^{\mathrm{bc}}$ & $1.71^{\mathrm{f}}$ & $1.22^{\mathrm{d}}$ & $14^{\mathrm{f}}$ \\
\hline $\begin{array}{l}\text { Chemical P }\left(20 \mathrm{~kg} \cdot \mathrm{ha}^{-1}\right)+\text { lime }\left(4 \text { tons } \cdot \mathrm{ha}^{-1}\right)+ \\
\text { VC }\left(5 \text { tons } \cdot \mathrm{ha}^{-1}\right)\end{array}$ & - & $5.94^{\mathrm{a}}$ & $1.04^{\mathrm{ij}}$ & $0.96^{\mathrm{h}}$ & $8^{\mathrm{h}}$ \\
\hline $\begin{array}{l}\text { Chemical P }\left(40 \mathrm{~kg} \cdot \mathrm{ha}^{-1}\right)+\text { lime }\left(4 \text { tons } \cdot \mathrm{ha}^{-1}\right)+ \\
\text { VC }\left(5 \text { tons } \cdot \mathrm{ha}^{-1}\right)\end{array}$ & - & $6.00^{\mathrm{a}}$ & $1.07^{\text {hij }}$ & $0.95^{\mathrm{h}}$ & $8^{\mathrm{h}}$ \\
\hline $\begin{array}{l}\text { Chemical P }\left(60 \mathrm{~kg} \cdot \mathrm{ha}^{-1}\right)+\text { lime }\left(2 \text { tons } \cdot \mathrm{ha}^{-1}\right)+ \\
\text { VC }\left(7.5 \text { tons } \cdot \mathrm{ha}^{-1}\right)\end{array}$ & - & $5.86^{\mathrm{ab}}$ & $1.13^{\text {ghi }}$ & $0.96^{\mathrm{h}}$ & $9^{\mathrm{h}}$ \\
\hline $\begin{array}{l}\text { Chemical P }\left(20 \mathrm{~kg} \cdot \mathrm{ha}^{-1}\right)+\text { lime }\left(4 \text { tons } \cdot \mathrm{ha}^{-1}\right)+ \\
\text { VC }\left(2.5 \text { tons }^{-h^{-1}}\right)\end{array}$ & - & $5.50^{\mathrm{cd}}$ & $1.13^{\text {ghi }}$ & $1.03^{\mathrm{g}}$ & $9^{\mathrm{h}}$ \\
\hline $\begin{array}{l}\text { Chemical P }\left(40 \mathrm{~kg} \cdot \mathrm{ha}^{-1}\right)+\text { lime }\left(2 \text { tons } \cdot \mathrm{ha}^{-1}\right)+ \\
\text { VC }\left(5 \text { tons } \cdot \mathrm{ha}^{-1}\right)\end{array}$ & - & $5.32^{\mathrm{d}-\mathrm{g}}$ & $1.90^{\mathrm{e}}$ & $1.16^{\mathrm{de}}$ & $15^{\mathrm{ef}}$ \\
\hline F-test & - & $* * *$ & $* * *$ & $* * *$ & $* * *$ \\
\hline $\mathrm{CV}(\%)$ & - & 2.03 & 2.51 & 2.55 & 5.14 \\
\hline
\end{tabular}

*Means followed by the same letter within a column are not significantly different at $P>0.001$; ${ }^{* * *}$ significant at $P \leq 0.001$ using Duncan's multiple range test; Ex. Ac, exchangeable acidity; Ex. Al, exchangeable aluminium; AS, acid saturation; chemical P, chemical phosphorus; VC, vermicompost; CV, coefficient of variation.

derived from decomposition of the organic matter by the activities of microorganisms. The contents of the VC could decrease soil acidity and enhance soil fertility in the strongly acidic soils of the study area. This is manifested by the high $\mathrm{pH}$ of the compost. In line with the findings of this study, Wael et al. [61] stated that VC was used to increase the $\mathrm{pH}$ in acidic soils and reduce $\mathrm{Al}$ and $\mathrm{Mn}$ toxicity because of its alkalinity. Arancon et al. [18] and Asciutto et al. [62] also reported that VC contains most nutrients, such as exchangeable $\mathrm{Ca}$, phosphates, and soluble $\mathrm{K}$ in plant available forms.

3.2. Effects of Treatments on $p H$, Exchangeable Acidity and Al, and Acid Saturation. The lime at each respective application level alone or in combination with VC had significant $(P \leq 0.001)$ effects on soil $\mathrm{pH}$, exchangeable acidity and $\mathrm{Al}$, and acid saturation (AS) (Table 3 ). The highest lime rate (6 tons. $\left.\mathrm{CaCO}_{3} \cdot \mathrm{ha}^{-1}\right)$ significantly $(P \leq 0.001)$ increased the $\mathrm{pH}$ from 4.80 to 6.01 , reduced both the exchangeable acidity and $\mathrm{Al}$ from 2.4 to $0.17 \mathrm{cmol}_{\mathrm{c}} \cdot \mathrm{kg}^{-1}$ and 1.70 to $0.33 \mathrm{cmol}_{\mathrm{c}} \cdot \mathrm{kg}^{-1}$, respectively, and reduced acid saturation from $30 \%$ to $1.62 \%$.
This might be because lime contains $\mathrm{Ca}^{2+}$ cation to exchange and/or replace $\mathrm{H}^{+}$ion on the exchange sites and anions such as $\mathrm{CO}_{3}{ }^{2-}$ to neutralize the $\mathrm{H}^{+}$ion released from the exchange sites and hydrolyzing $\mathrm{Al}$ species to the soil solution. In consent with the results of this study, Kisinyo et al. [63] and Kisinyo et al. [15] reported that application of lime to acid soils increased $\mathrm{Ca}^{2+}$ and/or $\mathrm{Mg}^{2+}$ ions and reduced $\mathrm{Al}^{3+}, \mathrm{H}^{+}$, $\mathrm{Mn}^{2+}$, and $\mathrm{Fe}^{2+}$ ions in the soil solution.

Vermicompost at each respective application levels had also significant $(P \leq 0.001)$ effects on the soil $\mathrm{pH}$, exchangeable acidity and $\mathrm{Al}$, and AS (Table 3 ). The rise in soil $\mathrm{pH}$ due to application of VC might be attributed to its high content of basic cations and $\mathrm{pH}$, which could reduce soil acidity and the contents of exchangeable acidity and $\mathrm{Al}$ through replacing the acidic cations from the exchange sites. This is in agreement with the findings of Angelova et al. [64] who pointed out that the direction of the change in soil $\mathrm{pH}$ as a result of $\mathrm{VC}$ application reflected the initial $\mathrm{pH}$ of $\mathrm{VC}$.

Generally, the combination of all lime-VC treatments significantly $(P \leq 0.001)$ increased soil $\mathrm{pH}$ and decreased exchangeable acidity and $\mathrm{Al}$ relative to the control (Table 3 ). Combination of the highest level of VC $\left(7.5\right.$ tons $\left.\cdot \mathrm{ha}^{-1}\right)$ with 
TABLE 4: Pearson correlation coefficients $\mathrm{r}$ among selected soil chemical properties.

\begin{tabular}{|c|c|c|c|c|c|c|c|c|c|c|c|}
\hline & $\mathrm{pH} 2 \mathrm{O}$ & Ex. Ac & Ex. Al & AS & $\mathrm{OM}$ & $\mathrm{TN}$ & $\mathrm{BP}$ & $\mathrm{Ca}$ & $\mathrm{Mg}$ & $\mathrm{K}$ & $\mathrm{Na}$ \\
\hline Ex Ac & $-0.87^{* *}$ & & & & & & & & & & \\
\hline Ex Al & $-0.87^{* *}$ & $0.93^{* *}$ & & & & & & & & & \\
\hline AS & $-0.88^{* *}$ & $0.92^{* *}$ & $0.87^{* *}$ & & & & & & & & \\
\hline $\mathrm{OM}$ & $0.55^{* *}$ & -0.26 & $-0.39^{*}$ & $-0.50^{* *}$ & & & & & & & \\
\hline $\mathrm{TN}$ & $0.75^{* *}$ & $-0.51^{* *}$ & $-0.63^{* *}$ & $-0.67^{* *}$ & $0.89^{* *}$ & & & & & & \\
\hline $\mathrm{BP}$ & $0.69^{* *}$ & $-0.56^{* *}$ & $-0.53^{* *}$ & $-0.66^{* *}$ & $0.57^{* *}$ & $0.65^{* *}$ & & & & & \\
\hline $\mathrm{Ca}$ & $0.72^{* *}$ & $-0.57^{* *}$ & $-0.59^{* *}$ & $-0.81^{* *}$ & $0.85^{* *}$ & $0.83^{* *}$ & $0.65^{* *}$ & & & & \\
\hline $\mathrm{Mg}$ & $0.78^{* *}$ & $0.78^{* *}$ & $-0.71^{* *}$ & $-0.80^{* *}$ & $0.81^{* *}$ & $0.85^{* *}$ & $0.59^{* *}$ & $0.91^{* *}$ & & & \\
\hline $\mathrm{K}$ & $0.84^{* *}$ & $-0.76^{* *}$ & $-0.81^{* *}$ & $-0.88^{* *}$ & $0.73^{* *}$ & $0.82^{* *}$ & $0.73^{* *}$ & $0.84^{* *}$ & $0.85^{* *}$ & & \\
\hline $\mathrm{Na}$ & $0.79^{* *}$ & $-0.75^{* *}$ & $-0.75^{* *}$ & $-0.89^{* *}$ & $0.62^{* *}$ & $0.74^{* *}$ & $0.73^{* *}$ & $0.81^{* *}$ & $0.76^{* *}$ & $0.91^{* *}$ & \\
\hline $\mathrm{Fe}$ & $-0.79^{* *}$ & $0.86^{* *}$ & $0.83^{* *}$ & $0.89^{* *}$ & $-0.31^{*}$ & $-0.54^{* *}$ & $-0.58^{* *}$ & $-0.64^{* *}$ & $-0.65^{* *}$ & $-0.65^{* *}$ & $-0.85^{* *}$ \\
\hline
\end{tabular}

${ }^{*, * *}$ Significant at 0.05 and 0.01 probability levels, respectively; Ex. Ac, exchangeable acidity; Ex. Al, exchangeable aluminium; AS, acid saturation; OM, organic matter; TN, total nitrogen; BP, Bray-II P.

lime ( 4 tons $\cdot \mathrm{ha}^{-1}$ ) increased $\mathrm{pH}$ from 4.80 to 6.05 and decreased exchangeable acidity and $\mathrm{Al}$ from 2.38 to $0.17 \mathrm{cmol}_{c^{\prime}} \mathrm{kg}^{-1}$ and 0.45 to $0.09 \mathrm{cmol}_{c} \cdot \mathrm{kg}^{-1}$, respectively (Table 3 ). When lime at a rate of 4 tons $\cdot \mathrm{ha}^{-1}$ was applied to the soil in combination with $\mathrm{VC}$ at the rate of 5 and 7.5 tons.ha ${ }^{-1}$, the soil $\mathrm{pH}$ increased to the optimum $\mathrm{pH}$ for many crops. The correlation analysis also indicated that the $\mathrm{pH}$ of the soils was correlated with the exchangeable acidity $\left(r=-0.87^{* *}, P \leq 0.01\right)$, exchangeable Al $\left(r=-0.87^{* *}, P \leq 0.01\right)$, and AS $\left(r=-0.88^{* *}, P \leq 0.01\right)$ (Table 4). This is in agreement with Opala et al. [65] who indicated that the combination of organic fertilizers having liming effect and inorganic fertilizers decreased exchangeable acidity which in turn increased soil $\mathrm{pH}$.

The chemical P fertilizer had no significant $(P \leq 0.001)$ effect on soil $\mathrm{pH}$, exchangeable acidity and $\mathrm{Al}$, and $\mathrm{AS}$ when applied alone over the control (Table 3). Along with this, Kisinyo et al. [63] reported that application of the P fertilizer alone to acidic soils did not increase the soil $\mathrm{pH}$ neither reduced soil exchangeable acidity.

3.3. Effects of Treatments on Organic Matter, Total Nitrogen, and Available Phosphorus. Compared to the control, all the other treatments showed significant $(P \leq 0.001)$ increase in soil OM except all levels of chemical $P$ and the combination of lime (4 tons $\mathrm{CaCO}_{3} \cdot \mathrm{ha}^{-1}$ ) with all levels of the chemical $\mathrm{P}$ fertilizer (Table 5). The highest content of OM (4.1\%) was obtained when the soil was treated by the combination of lime ( 4 tons $\mathrm{CaCO}_{3} \cdot \mathrm{ha}^{-1}$ ) with highest level of VC $\left(7.5\right.$ tons $\cdot \mathrm{ha}^{-1}$ ) (Table 5). Lime and VC application either individually or in combination increased soil $\mathrm{pH}$ and $\mathrm{OM}$ content, which in turn enhances the microbial population. An increase in $\mathrm{pH}$ may decrease the stress on soil microbes and microbial activity and thus increases soil OM. This is supported by the correlation in which $\mathrm{pH}$ was positively and significantly $\left(r=0.55^{* *} ; P \leq 0.01\right)$ correlated with OM (Table 4). In agreement with this, Amba et al. [66] indicated that soil OC increment after the application of lime and manure was associated with the general improvement of soil conditions.

The application of treatments significantly $(P \leq 0.001)$ increased soil total $\mathrm{N}$ except the three rates of the chemical $\mathrm{P}$ fertilizer alone (Table 5). The application of OM in the form of $\mathrm{VC}$ is expected to increase the OM and TN contents of the soil.
This is also evidenced by the total by the positive and significant correlation between total $\mathrm{N}\left(r=0.89^{* *} ; P \leq 0.01\right)$ and OM (Table 4). This is in agreement with Adeleye et al. [67] and Efthimiadou et al. [68] who stated that soil total $\mathrm{N}$ increases when biofertilizers are solely applied due to the addition of OM. Mary and Sivagami [69] also reported that VC is rich in total $\mathrm{N}$. The highest increment of total $\mathrm{N}\left(0.29 \mathrm{mg} \cdot \mathrm{kg}^{-1}\right)$ was obtained when lime ( 4 tons.ha $\left.{ }^{-1}\right)$ was applied in combination with VC (7.5 tons $\cdot \mathrm{ha}^{-1}$ ) (Table 5). Similar to the results of the current study, Biruk et al. [34] reported increase in total $\mathrm{N}$ in acidic soils treated with lime and compost.

The available $\mathrm{P}$ of the soil varied from 4.5 to $8.3 \mathrm{mg} \cdot \mathrm{kg}^{-1}$ after incubation (Table 5). The highest available $\mathrm{P}$ was obtained when chemical P $\left(60 \mathrm{~kg} \cdot \mathrm{P} \cdot \mathrm{ha}^{-1}\right)$, lime $\left(2\right.$ tons $\left.\cdot \mathrm{ha}^{-1}\right)$, and VC (5 tons $\left.\cdot \mathrm{ha}^{-1}\right)$ were applied in combination. Therefore, the application of the treatments at these rates significantly $(P \leq 0.0001)$ increased available $\mathrm{P}$ by $45 \%$ over the control (Table 5). This might be due to the significant $(P \leq 0.001)$ increase in soil $\mathrm{pH}$ due to the effect of lime and $\mathrm{VC}$, which in turn reduced $\mathrm{P}$ fixation. This is also supported by the results of the simple correlation analysis which indicated that the available $\mathrm{P}$ of the soil was positively and significantly correlated to the $\mathrm{pH}\left(r=0.69^{* *}, P \leq 0.01\right)$ (Table 4). This is in harmony with the findings of Anetor and Akinrinde [70] who indicated that increase in soil $\mathrm{pH}$ due to lime application reduced P fixation. Similarly, Kisinyo et al. [63] reported that the application of lime and chemical $P$ fertilizer in sole or combination had significantly positive effect on soil $\mathrm{pH}$ and available $\mathrm{P}$ in acid soils. Application of the $\mathrm{P}$ fertilizer increased available $\mathrm{P}$ due to increase of $\mathrm{P}$ in soil. Similar increase in soil available P in tropical soils has been reported by Kisinyo et al. [15] and Opala et al. [4]. Combined application of chemical P and VC increased soil available $\mathrm{P}$ more than when either of them were applied alone. This was because the organic material reduced soil $\mathrm{P}$ sorption making both the soil native $\mathrm{P}$ and the applied $\mathrm{P}$ fertilizer available for plant uptake. Similar results were reported by Kisinyo [71] and Opala et al. [72].

3.4. Effects of Treatments on Exchangeable Bases and Effective Cation Exchange Capacity. Soil exchangeable Ca was significantly $(P \leq 0.001)$ increased by the application of 
TABLE 5: Effects of treatments on organic matter, total nitrogen, and available phosphorus of the soil after incubation.

\begin{tabular}{|c|c|c|c|c|}
\hline Treatment & Rate & $\mathrm{OM}$ & $\%$ & Bray $\mathrm{mg} \cdot \mathrm{kg}^{-1}$ II P \\
\hline \multirow[t]{2}{*}{ Control } & 0 & $2.13^{1}$ & $0.20^{\mathrm{ij}}$ & $4.5^{1}$ \\
\hline & 2 & $2.17^{\mathrm{jkl}}$ & $0.21^{\text {hi }}$ & $5.6^{\mathrm{k}}$ \\
\hline \multirow[t]{3}{*}{ Lime (tons $\cdot \mathrm{ha}^{-1}$ ) } & 4 & $2.21^{\mathrm{jk}}$ & $0.21^{\mathrm{hi}}$ & $6.3^{\text {gh }}$ \\
\hline & 6 & $2.28^{\mathrm{i}}$ & $0.23^{\text {gh }}$ & $6.2^{\mathrm{h}}$ \\
\hline & 20 & $2.17^{\mathrm{jkl}}$ & $0.20^{\mathrm{ij}}$ & $5.7^{\mathrm{jk}}$ \\
\hline \multirow{3}{*}{ Chemical P $\left(\mathrm{kg} \cdot \mathrm{ha}^{-1}\right)$} & 40 & $2.14^{1}$ & $0.19^{j}$ & $6.0^{\mathrm{i}}$ \\
\hline & 60 & $2.16^{\mathrm{kl}}$ & $0.21^{\mathrm{hi}}$ & $6.2^{\mathrm{h}}$ \\
\hline & 2.5 & $2.72^{\mathrm{h}}$ & $0.21^{\mathrm{hi}}$ & $5.8^{\mathrm{ij}}$ \\
\hline \multirow[t]{3}{*}{$\mathrm{VC}\left(\right.$ tons $\cdot \mathrm{ha}^{-1}$ ) } & 5.0 & $3.20^{\mathrm{f}}$ & $0.23^{\mathrm{gh}}$ & $6.0^{\mathrm{i}}$ \\
\hline & 7.5 & $3.99^{\mathrm{b}}$ & $0.27^{\mathrm{abc}}$ & $6.3^{\mathrm{gh}}$ \\
\hline & 20 & $2.24^{\mathrm{ij}}$ & $0.22^{\mathrm{hi}}$ & $6.5^{\mathrm{f}}$ \\
\hline \multirow[t]{3}{*}{ Chemical P $\left(\mathrm{kg} \cdot \mathrm{ha}^{-1}\right)+$ lime $\left(4\right.$ tons $\left.\cdot \mathrm{ha}^{-1}\right)$} & 40 & $2.19^{\mathrm{jkl}}$ & $0.21^{\mathrm{hi}}$ & $6.9^{e}$ \\
\hline & 60 & $2.19^{\mathrm{jkl}}$ & $0.21^{\mathrm{hi}}$ & $7.6^{\mathrm{bc}}$ \\
\hline & 2.5 & $3.02^{\mathrm{g}}$ & $0.25^{\mathrm{edf}}$ & $6.5^{\mathrm{f}}$ \\
\hline \multirow[t]{3}{*}{$\mathrm{VC}\left(\right.$ tons $\left.\cdot \mathrm{ha}^{-1}\right)+$ lime $\left(4\right.$ tons $\left.\cdot \mathrm{ha}^{-1}\right)$} & 5.0 & $3.49^{\mathrm{d}}$ & $0.26^{\text {cde }}$ & $6.9^{\mathrm{e}}$ \\
\hline & 7.5 & $4.10^{\mathrm{a}}$ & $0.29^{\mathrm{a}}$ & $7.3^{\mathrm{d}}$ \\
\hline & 20 & $3.20^{f}$ & $0.23^{\text {gh }}$ & $6.4^{\mathrm{fg}}$ \\
\hline \multirow[t]{2}{*}{ Chemical P $\left(\mathrm{kg} \cdot \mathrm{ha}^{-1}\right)+\mathrm{VC}\left(5\right.$ tons $\left.\cdot \mathrm{ha}^{-1}\right)$} & 40 & $3.21^{\mathrm{f}}$ & $0.22^{\text {hi }}$ & $6.4^{\mathrm{fg}}$ \\
\hline & 60 & $3.48^{\mathrm{d}}$ & $0.25^{\mathrm{edf}}$ & $7.7^{\mathrm{b}}$ \\
\hline $\begin{array}{l}\text { Chemical P }\left(20 \mathrm{~kg} \cdot \mathrm{ha}^{-1}\right)+\text { lime }\left(4 \text { tons } \cdot \mathrm{ha}^{-1}\right)+ \\
\text { VC }\left(5 \text { tons } \cdot \mathrm{ha}^{-1}\right)\end{array}$ & - & $3.40^{\mathrm{e}}$ & $0.26^{\text {cde }}$ & $7.4^{\mathrm{cd}}$ \\
\hline $\begin{array}{l}\text { Chemical P }\left(40 \mathrm{~kg} \cdot \mathrm{ha}^{-1}\right)+\text { lime }\left(4 \text { tons } \cdot \mathrm{ha}^{-1}\right)+ \\
\text { VC }\left(5 \text { tons } \cdot \mathrm{ha}^{-1}\right)\end{array}$ & - & $3.50^{\mathrm{d}}$ & $0.26^{\text {cde }}$ & $7.6^{\mathrm{bc}}$ \\
\hline $\begin{array}{l}\text { Chemical P }\left(60 \mathrm{~kg} \cdot \mathrm{ha}^{-1}\right)+\text { lime }\left(2 \text { tons } \cdot \mathrm{ha}^{-1}\right)+ \\
\text { VC }\left(7.5 \text { tons } \cdot \mathrm{ha}^{-1}\right)\end{array}$ & - & $3.92^{\mathrm{c}}$ & $0.28^{\mathrm{ab}}$ & $8.3^{\mathrm{a}}$ \\
\hline $\begin{array}{l}\text { Chemical P }\left(20 \mathrm{~kg} \cdot \mathrm{ha}^{-1}\right)+\text { lime }\left(4 \text { tons } \mathrm{ha}^{-1}\right)+ \\
\text { VC }\left(2.5 \text { tons } \cdot \mathrm{ha}^{-1}\right)\end{array}$ & - & $2.99^{\mathrm{g}}$ & $0.25^{\mathrm{edf}}$ & $7.0^{\mathrm{e}}$ \\
\hline $\begin{array}{l}\text { Chemical P }\left(60 \mathrm{~kg} \cdot \mathrm{ha}^{-1}\right)+\text { lime }\left(2 \text { tons } \cdot \mathrm{ha}^{-1}\right)+ \\
\text { VC }\left(5 \text { tons } \cdot \mathrm{ha}^{-1}\right)\end{array}$ & - & $3.22^{\mathrm{f}}$ & $0.24^{\mathrm{fg}}$ & $7.3^{\mathrm{d}}$ \\
\hline$F$-test & - & $* * *$ & $* * *$ & $* * *$ \\
\hline $\mathrm{CV}(\%)$ & - & 1 & 3.64 & 1.41 \\
\hline
\end{tabular}

${ }^{*}$ Means followed by the same letter within a column are not significantly different at $P>0.001$; ${ }^{* * *}$ significant at $P \leq 0.001$ using Duncan's multiple range test; $\mathrm{OM}$, organic matter; $\mathrm{TN}$, total nitrogen; $\mathrm{C} / \mathrm{N}$, carbon to nitrogen ratio; chemical $\mathrm{P}$, chemical phosphorus; VC, vermicompost; $\mathrm{CV}$, coefficient of variation.

all treatments except the application of chemical $\mathrm{P}$ alone (Table 6). The highest $\left(7.7 \mathrm{cmol}_{\mathrm{c}} \cdot \mathrm{kg}^{-1}\right)$ and lowest $\left(3.5 \mathrm{cmol}_{\mathrm{c}} \cdot \mathrm{kg}^{-1}\right)$ soil exchangeable $\mathrm{Ca}$ was obtained when the soil was treated by VC $\left(7.5\right.$ tons $\left.\cdot \mathrm{ha}^{-1}\right)$ plus lime $\left(4\right.$ tons $\left.\cdot \mathrm{ha}^{-1}\right)$ and chemical P $\left(40 \mathrm{~kg} \cdot \mathrm{ha}^{-1}\right)$, respectively, relative to the control (Table 6). Furthermore, lime and VC when applied separately increased soil exchangeable Ca over the control (Table 6). The increase in exchangeable $\mathrm{Ca}$ due to the combined use of lime and VC could be associated with the release of $\mathrm{Ca}^{2+}$ from the applied lime through its dissolution and vermicompost, which replaces the acidic cations from the exchange site. Therefore, the most effective and significant increase was observed when VC was combined with lime plus the chemical P fertilizer. This is in agreement with the previous works of Hassen et al. [73] and Adeleye et al. [67] who reported increase in exchangeable Ca following combined application of lime and organic fertilizers.

Soil exchangeable $\mathrm{Mg}$ was also significantly $(P \leq 0.001)$ increased as a result of the treatments applied except the chemical $\mathrm{P}$ fertilizer (Table 6). Accordingly, the highest exchangeable $\mathrm{Mg}\left(3.44 \mathrm{cmol}_{\mathrm{c}} \cdot \mathrm{kg}^{-1}\right)$ was recorded from in the application of lime ( 4 tons $\left.\cdot \mathrm{ha}^{-1}\right)$ with $\mathrm{VC}\left(7.5\right.$ tons $\left.\cdot \mathrm{ha}^{-1}\right)$ (Table 6). The increased soil exchangeable $\mathrm{Mg}$ as a result of lime and VC application might be attributed to increase in soil $\mathrm{pH}$ which in turn may have increased $\mathrm{Mg}$ availability in the soil. When VC was combined with lime and chemical P fertilizer, soil exchangeable $\mathrm{Mg}$ was increased, and this was attributed to addition of nutrients to the soil from the VC. In addition, the increase of soil $\mathrm{pH}$ by $\mathrm{VC}$ reduces $\mathrm{Al}^{3+}$ and $\mathrm{H}^{+}$ content in soil exchange sites and then increased $\mathrm{Mg}$ availability. The results are in agreement with those of Repsiene and Skuodiene [74] and Andric et al. [75] who reported that soil exchangeable bases increased when acidic soil was amended by lime and manure.

The increase in soil exchangeable $\mathrm{K}$ and $\mathrm{Na}$ due to application of VC alone or in combination with the P fertilizer plus lime could be due to added $\mathrm{K}$ and $\mathrm{Na}$ from VC. The VC used in the current study had 27.7 and $14.2 \mathrm{cmol}_{\mathrm{C}} \cdot \mathrm{kg}^{-1}$ of $\mathrm{K}$ and $\mathrm{Na}$ contents, respectively, which might have added significant amounts of these nutrients to the soil (Table 2). This is supported by the report of Ayeni and Adetunji [76], Adeleye et al. [67], and Adeniyan et al. [77] who indicated that soil exchangeable bases increase when the biofertilizer was applied alone or in combination with the lime and $\mathrm{P}$ fertilizer.

The effective cation exchange capacity (ECEC) of the soil was significantly $(P \leq 0.001)$ affected by all treatments except 
TABLE 6: Effects of treatments on exchangeable bases and effective cation exchange capacity.

\begin{tabular}{|c|c|c|c|c|c|c|}
\hline Treatment & Rate & Ex. Ca & Ex. Mg & $\begin{array}{l}\text { Ex. K } \\
\mathrm{cmol}_{\mathrm{c}} \cdot \mathrm{kg}^{-1}\end{array}$ & Ex. $\mathrm{Na}$ & ECEC \\
\hline \multirow[t]{2}{*}{ Control } & - & $3.5^{\mathrm{i}}$ & $1.52^{\mathrm{k}}$ & $0.25^{\mathrm{j}}$ & $0.16^{j}$ & $7.85^{\mathrm{h}}$ \\
\hline & 2 & $4.5^{\mathrm{h}}$ & $1.65^{\mathrm{j}}$ & $0.31^{\mathrm{i}}$ & $0.78^{\mathrm{h}}$ & $9.37^{\mathrm{g}}$ \\
\hline \multirow[t]{3}{*}{ Lime (tons $\cdot \mathrm{ha}^{-1}$ ) } & 4 & $5.2^{\mathrm{g}}$ & $1.88^{\mathrm{h}}$ & $0.41^{\mathrm{d}-\mathrm{g}}$ & $0.90^{\text {efg }}$ & $9.57^{\mathrm{g}}$ \\
\hline & 6 & $5.9^{\mathrm{fg}}$ & $3.09^{\mathrm{b}}$ & $0.42^{\mathrm{de}}$ & $0.97^{\mathrm{d}}$ & $10.49^{\mathrm{f}}$ \\
\hline & 20 & $4.7^{\mathrm{h}}$ & $1.58^{\mathrm{k}}$ & $0.24^{\mathrm{j}}$ & $0.17^{\mathrm{j}}$ & $9.00^{\mathrm{g}}$ \\
\hline \multirow[t]{3}{*}{ Chemical P $\left(\mathrm{kg} \cdot \mathrm{ha}^{-1}\right)$} & 40 & $3.5^{\mathrm{i}}$ & $1.53^{\mathrm{k}}$ & $0.25^{\mathrm{j}}$ & $0.16^{j}$ & $7.80^{\mathrm{h}}$ \\
\hline & 60 & $3.7^{\mathrm{i}}$ & $1.52^{\mathrm{k}}$ & $0.23^{\mathrm{j}}$ & $0.18^{j}$ & $7.96^{\mathrm{h}}$ \\
\hline & 2.5 & $5.9^{\mathrm{fg}}$ & $2.34^{\mathrm{g}}$ & $0.33^{\text {hi }}$ & $0.27^{\mathrm{i}}$ & $10.96^{\mathrm{f}}$ \\
\hline \multirow{3}{*}{ VC (tons $\cdot \mathrm{ha}^{-1}$ ) } & 5 & $6.4^{\mathrm{def}}$ & $2.43^{\mathrm{f}}$ & $0.37^{\text {gh }}$ & $0.86^{\mathrm{g}}$ & $12.15^{\mathrm{de}}$ \\
\hline & 7.5 & $6.6^{\text {cde }}$ & $2.67^{\mathrm{e}}$ & $0.43^{\mathrm{cd}}$ & $0.94^{\mathrm{de}}$ & $12.59^{\mathrm{bcd}}$ \\
\hline & 20 & $5.3^{\mathrm{g}}$ & $1.81^{\mathrm{i}}$ & $0.39^{\text {efg }}$ & $0.98^{\mathrm{d}}$ & $9.63^{\mathrm{g}}$ \\
\hline \multirow{3}{*}{ Chemical P $\left(\mathrm{kg} \cdot \mathrm{ha}^{-1}\right)+$ lime $\left(4\right.$ tons $\left.\cdot \mathrm{ha}^{-1}\right)$} & 40 & $5.3^{\mathrm{g}}$ & $1.85^{\mathrm{hi}}$ & $0.39^{\mathrm{d}-\mathrm{g}}$ & $0.95^{\mathrm{de}}$ & $9.60^{\mathrm{g}}$ \\
\hline & 60 & $5.3^{\mathrm{g}}$ & $1.85^{\mathrm{hi}}$ & $0.40^{\mathrm{d}-\mathrm{g}}$ & $0.93^{\mathrm{def}}$ & $9.57^{\mathrm{g}}$ \\
\hline & 2.5 & $6.9^{\mathrm{bcd}}$ & $2.99^{c}$ & $0.41^{\mathrm{def}}$ & $1.03^{\mathrm{c}}$ & $12.46^{\text {cde }}$ \\
\hline \multirow[t]{3}{*}{$\mathrm{VC}\left(\right.$ tons $\left.\cdot \mathrm{ha}^{-1}\right)+$ lime $\left(4\right.$ tons $\left.\cdot \mathrm{ha}^{-1}\right)$} & 5 & $7.2^{\mathrm{ab}}$ & $3.08^{\mathrm{b}}$ & $0.49^{\mathrm{b}}$ & $1.13^{\mathrm{b}}$ & $12.91^{\mathrm{abc}}$ \\
\hline & 7.5 & $7.7^{\mathrm{a}}$ & $3.44^{\mathrm{a}}$ & $0.58^{\mathrm{a}}$ & $1.22^{\mathrm{a}}$ & $13.38^{\mathrm{a}}$ \\
\hline & 20 & $6.4^{\mathrm{def}}$ & $2.42^{\mathrm{f}}$ & $0.37^{\mathrm{gh}}$ & $0.85^{\mathrm{g}}$ & $12.12^{\mathrm{de}}$ \\
\hline \multirow[t]{2}{*}{ Chemical P $\left(\mathrm{kg} \cdot \mathrm{ha}^{-1}\right)+\mathrm{VC}\left(5\right.$ tons $\left.\cdot \mathrm{ha}^{-1}\right)$} & 40 & $6.5^{\mathrm{def}}$ & $2.45^{\mathrm{f}}$ & $0.37^{\text {gh }}$ & $0.88^{\mathrm{fg}}$ & $12.22^{\mathrm{de}}$ \\
\hline & 60 & $6.5^{\mathrm{def}}$ & $2.44^{\mathrm{f}}$ & $0.40^{\mathrm{d}-\mathrm{g}}$ & $0.86^{\mathrm{g}}$ & $11.85^{\mathrm{e}}$ \\
\hline $\begin{array}{l}\text { Chemical P }\left(20 \mathrm{~kg} \cdot \mathrm{ha}^{-1}\right)+\text { lime }\left(4 \text { tons } \cdot \mathrm{ha}^{-1}\right)+ \\
\text { VC }\left(5 \text { tons } \cdot \mathrm{ha}^{-1}\right)\end{array}$ & - & $7.2^{\mathrm{ab}}$ & $3.08^{\mathrm{b}}$ & $0.46^{\mathrm{bc}}$ & $1.13^{\mathrm{b}}$ & $12.90^{\mathrm{abc}}$ \\
\hline $\begin{array}{l}\text { Chemical P }\left(40 \mathrm{~kg} \cdot \mathrm{ha}^{-1}\right)+\text { lime }\left(4 \text { tons } \cdot \mathrm{ha}^{-1}\right)+ \\
\text { VC }\left(5 \text { tons } \cdot \mathrm{ha}^{-1}\right)\end{array}$ & - & $7.2^{\mathrm{ab}}$ & $3.05^{\mathrm{b}}$ & $0.47^{\mathrm{bc}}$ & $1.12^{\mathrm{b}}$ & $12.92^{\mathrm{abc}}$ \\
\hline $\begin{array}{l}\text { Chemical P }\left(60 \mathrm{~kg} \cdot \mathrm{ha}^{-1}\right)+\text { lime }\left(2 \text { tons } \cdot \mathrm{ha}^{-1}\right)+ \\
\text { VC }\left(7.5 \text { tons } \cdot \mathrm{ha}^{-1}\right)\end{array}$ & - & $7.1^{\mathrm{abc}}$ & $3.10^{\mathrm{b}}$ & $0.49^{\mathrm{b}}$ & $1.25^{\mathrm{a}}$ & $13.10^{\mathrm{ab}}$ \\
\hline $\begin{array}{l}\text { Chemical P }\left(20 \mathrm{~kg} \cdot \mathrm{ha}^{-1}\right)+\text { lime }\left(4 \text { tons } \cdot \mathrm{ha}^{-1}\right)+ \\
\text { VC }\left(2.5 \text { tons } \cdot \mathrm{ha}^{-1}\right)\end{array}$ & - & $6.9^{\mathrm{bcd}}$ & $2.94^{\mathrm{c}}$ & $0.42^{\text {de }}$ & $1.05^{\mathrm{c}}$ & $12.48^{\mathrm{b}-\mathrm{e}}$ \\
\hline $\begin{array}{l}\text { Chemical P }\left(40 \mathrm{~kg} \cdot \mathrm{ha}^{-1}\right)+\text { lime }\left(2 \text { tons } \cdot \mathrm{ha}^{-1}\right)+ \\
\text { VC }\left(5 \text { tons } \cdot \mathrm{ha}^{-1}\right)\end{array}$ & - & $6.1^{\mathrm{ef}}$ & $2.84^{\mathrm{d}}$ & $0.47^{\mathrm{bc}}$ & $1.07^{\mathrm{c}}$ & $12.34^{\text {cde }}$ \\
\hline$F$-test & - & $* * *$ & $* * *$ & $* * *$ & $* * *$ & $* * *$ \\
\hline CV (\%) & - & 4.5 & 1.18 & 4.63 & 3 & 2.46 \\
\hline
\end{tabular}

${ }^{*}$ Means followed by the same letter within a column are not significantly different at $P>0.001$; $^{* * *}$ significant at $P \leq 0.001$ using Duncan's multiple range test; Ex. Ca, exchangeable calcium; Ex. Mg, exchangeable magnesium; Ex. K, exchangeable potassium; Ex. Na, exchangeable sodium; ECEC, effective cation exchange capacity; chemical P, chemical phosphorus; VC, vermicompost; CV, coefficient of variation.

the chemical $P$ fertilizer when applied at the rate of 40 and $60 \mathrm{~kg} \cdot \mathrm{P} \cdot \mathrm{ha}^{-1}$ (Table 6). This increase was due to improved soil conditions such as soil $\mathrm{pH}$, increased soil $\mathrm{Ca}, \mathrm{Mg}, \mathrm{K}$, and $\mathrm{Na}$ by VC and lime and increase of negative charges on the surfaces of the soil colloids following the rise in $\mathrm{pH}$. The ECEC increment might also be caused by deprotonation of $\mathrm{pH}$-dependent charge sites arising from VC. This is in agreement with the findings of Edmeades [78] who stated that ECEC increased with increasing $\mathrm{pH}$ of soils. The ECEC was significantly increased with the increase of $\mathrm{VC}$ due to the greater contents of exchangeable bases of VC. This is supported by Pandey and Shukla [79] who indicated that application of VC changed ECEC of the soil due to the change of negative surfaces of the soil colloids.

\subsection{Effects of Treatments on Extractable Micronutrients (Fe,} $\mathrm{Mn}, \mathrm{Zn}$, and $\mathrm{Cu}$ ). The extractable micronutrients were significantly $(P \leq 0.001)$ affected by treatments (Table 7$)$. Under almost all the treatments, all extractable micronutrients decreased relative to the control (Table 7). The extractability of Fe, $\mathrm{Mn}, \mathrm{Zn}$, and $\mathrm{Cu}$ tends to decrease as soil $\mathrm{pH}$ increased. The exact mechanisms responsible for reducing availability differ for each nutrient, but can include formation of low solubility compounds, greater retention by soil colloids when lime and VC are applied.

The decrease in extractable Fe may be due to the change in $\mathrm{pH}$ caused by the amendments because the bioavailability of DTPA-extractable Fe was decreased when $\mathrm{pH}$ of the soil increased. In consent with this, Imerb et al. [80] and Wael et al. [61] reported that extractable Fe decreased at $\mathrm{pH}$ levels near neutral or higher. The application of lime and VC decreased extractable Mn as compared with the control. This might be due to high CEC of organic fertilizer and its ability to form chelate complexes with this nutrient. Along with this, Angelova et al. [64] reported that the application of amendments decreased the extractable Mn concentration in the soil which might be due to immobilization of Mn by the application of VC. Extractable $\mathrm{Zn}$ was decreased significantly $(P \leq 0.001)$ by the application of lime and VC and also in combination of all treatments. This may be due to the increment of soil $\mathrm{pH}$ and also the formation of insoluble form of $\mathrm{Zn}$ compound when it reacts with VC. This in agreement with Walker et al. [81] who pointed out that $\mathrm{Zn}$ availability is controlled by soil pH. Angelova et al. [64] also indicated that $\mathrm{Zn}$ can form insoluble compound precipitates 
Table 7: The effects of treatments on extractable micronutrients ( $\mathrm{Fe}, \mathrm{Mn}, \mathrm{Zn}$, and $\mathrm{Cu}$ ) of the soil of the study area.

\begin{tabular}{|c|c|c|c|c|c|}
\hline Treatment & Rate & $\mathrm{Fe}$ & $\mathrm{Mn}$ & $\mathrm{Zn}$ & $\mathrm{Cu}$ \\
\hline \multirow[t]{2}{*}{ Control } & 0 & $40^{\mathrm{a}}$ & $36^{\mathrm{a}}$ & $3.06^{\mathrm{a}}$ & $3.65^{\mathrm{a}}$ \\
\hline & 2 & $24.1^{\mathrm{c}}$ & $31^{\mathrm{d}}$ & $2.96^{\mathrm{bc}}$ & $3.43^{\mathrm{b}}$ \\
\hline \multirow[t]{3}{*}{ Lime (tons $\cdot$ ha $^{-1}$ ) } & 4 & $16.6^{\mathrm{d}}$ & $25^{\mathrm{h}}$ & $2.41^{\mathrm{e}}$ & $3.15^{\mathrm{d}}$ \\
\hline & 6 & $14.3^{\mathrm{e}}$ & $17^{\mathrm{k}}$ & $2.23^{\mathrm{f}}$ & $2.86^{\mathrm{h}}$ \\
\hline & 20 & $39.7^{\mathrm{a}}$ & $36^{\mathrm{a}}$ & $3.09^{\mathrm{a}}$ & $3.66^{\mathrm{a}}$ \\
\hline \multirow[t]{3}{*}{ Chemical P $\left(\mathrm{kg} \cdot \mathrm{ha}^{-1}\right)$} & 40 & $40.5^{\mathrm{a}}$ & $36^{\mathrm{a}}$ & $3.08^{\mathrm{a}}$ & $3.65^{\mathrm{a}}$ \\
\hline & 60 & $40^{\mathrm{a}}$ & $36^{\mathrm{a}}$ & $3.03^{\mathrm{ab}}$ & $3.71^{\mathrm{a}}$ \\
\hline & 2.5 & $30.7^{\mathrm{b}}$ & $35^{\mathrm{b}}$ & $2.99^{\mathrm{b}}$ & $3.32^{c}$ \\
\hline \multirow[t]{3}{*}{$\mathrm{VC}\left(\right.$ tons $\left.\cdot \mathrm{ha}^{-1}\right)$} & 5 & $29.8^{\mathrm{b}}$ & $33^{c}$ & $2.90^{c}$ & $3.16^{\mathrm{d}}$ \\
\hline & 7.5 & $29.8^{\mathrm{b}}$ & $26^{\mathrm{g}}$ & $2.78^{\mathrm{d}}$ & $2.98^{\mathrm{ef}}$ \\
\hline & 20 & $16.6^{\mathrm{d}}$ & $24^{\mathrm{h}}$ & $2.43^{\mathrm{e}}$ & $3.14^{\mathrm{d}}$ \\
\hline \multirow[t]{3}{*}{ Chemical P $\left(\mathrm{kg} \cdot \mathrm{ha}^{-1}\right)+$ lime $\left(4\right.$ tons $\left.\cdot \mathrm{ha}^{-1}\right)$} & 40 & $16.6^{\mathrm{d}}$ & $25^{\mathrm{h}}$ & $2.42^{\mathrm{e}}$ & $3.16^{\mathrm{d}}$ \\
\hline & 60 & $16.6^{\mathrm{d}}$ & $25^{\mathrm{h}}$ & $2.44^{\mathrm{e}}$ & $3.16^{\mathrm{d}}$ \\
\hline & 2.5 & $15^{\mathrm{de}}$ & $22^{\mathrm{i}}$ & $2.24^{\mathrm{f}}$ & $2.96^{\mathrm{ef}}$ \\
\hline \multirow[t]{3}{*}{ VC (tons $\left.\cdot \mathrm{ha}^{-1}\right)+$ lime $\left(4\right.$ tons $\left.\cdot \mathrm{ha}^{-1}\right)$} & 5 & $10.8^{\mathrm{f}}$ & $16^{1}$ & $2.13^{\mathrm{g}}$ & $2.88^{\text {gh }}$ \\
\hline & 7.5 & $10.3^{\mathrm{f}}$ & $15^{\mathrm{m}}$ & $2.00^{\mathrm{h}}$ & $2.79^{\mathrm{i}}$ \\
\hline & 20 & $29.8^{\mathrm{b}}$ & $33^{c}$ & $2.90^{c}$ & $3.16^{\mathrm{d}}$ \\
\hline \multirow[t]{2}{*}{ Chemical P $\left(\mathrm{kg} \cdot \mathrm{ha}^{-1}\right)+\mathrm{VC}\left(5\right.$ tons $\left.\cdot \mathrm{ha}^{-1}\right)$} & 40 & $29.6^{\mathrm{b}}$ & $33^{c}$ & $2.91^{\mathrm{c}}$ & $3.15^{\mathrm{d}}$ \\
\hline & 60 & $31.2^{\mathrm{b}}$ & $30^{\mathrm{e}}$ & $2.99^{\mathrm{b}}$ & $3.15^{\mathrm{d}}$ \\
\hline $\begin{array}{l}\text { Chemical P }\left(20 \mathrm{~kg} \cdot \mathrm{ha}^{-1}\right)+\text { lime }\left(4 \text { tons } \cdot \mathrm{ha}^{-1}\right)+ \\
\text { VC }\left(5 \text { tons } \cdot \mathrm{ha}^{-1}\right)\end{array}$ & - & $10.8^{\mathrm{f}}$ & $16^{1}$ & $2.14^{\mathrm{g}}$ & $2.93^{\mathrm{fg}}$ \\
\hline $\begin{array}{l}\text { Chemical } \mathrm{P}\left(40 \mathrm{~kg} \cdot \mathrm{ha}^{-1}\right)+\text { lime }\left(4 \text { tons } \cdot \mathrm{ha}^{-1}\right)+ \\
\text { VC }\left(5 \text { tons } \cdot \mathrm{ha}^{-1}\right)\end{array}$ & - & $10.8^{\mathrm{f}}$ & $16^{1}$ & $2.15^{\mathrm{g}}$ & $2.88^{\mathrm{gh}}$ \\
\hline $\begin{array}{l}\text { Chemical P }\left(60 \mathrm{~kg} \cdot \mathrm{ha}^{-1}\right)+\text { lime }\left(2 \text { tons } \cdot \mathrm{ha}^{-1}\right)+ \\
\text { VC }\left(7.5 \text { tons } \cdot \mathrm{ha}^{-1}\right)\end{array}$ & - & $24.11^{\mathrm{c}}$ & $20^{\mathrm{j}}$ & $2.99^{\mathrm{b}}$ & $3.00^{\mathrm{e}}$ \\
\hline $\begin{array}{l}\text { Chemical P }\left(20 \mathrm{~kg} \cdot \mathrm{ha}^{-1}\right)+\text { lime }\left(4 \text { tons } \cdot \mathrm{ha}^{-1}\right)+ \\
\text { VC }\left(2.5 \text { tons }^{-h^{-1}}\right)\end{array}$ & - & $14.9^{\mathrm{de}}$ & $22^{\mathrm{i}}$ & $2.25^{\mathrm{f}}$ & $2.95^{\mathrm{ef}}$ \\
\hline $\begin{array}{l}\text { Chemical P }\left(40 \mathrm{~kg} \cdot \mathrm{ha}^{-1}\right)+\text { lime }\left(2 \text { tons } \cdot \mathrm{ha}^{-1}\right)+ \\
\text { VC }\left(5 \text { tons } \cdot \mathrm{ha}^{-1}\right)\end{array}$ & - & $15.4^{\mathrm{de}}$ & $27^{\mathrm{f}}$ & $2.47^{\mathrm{e}}$ & $3.14^{\mathrm{d}}$ \\
\hline F-test & - & $* * *$ & $* * *$ & $* * *$ & $* * *$ \\
\hline $\mathrm{CV}(\%)$ & - & 3.14 & 1.03 & 1.23 & 0.92 \\
\hline
\end{tabular}

*Means followed by the same letter within a column are not significantly different at $P>0.001$; ${ }^{* * *}$ significant at $P \leq 0.001$ using Duncan's multiple range test; chemical P, chemical phosphorus; VC, vermicompost; CV, coefficient of variation.

during the mineralization of organic ameliorants. The extractable $\mathrm{Cu}$ was decreased by the application of amendments. Especially, VC supplements lead to lower content of DTPA-extractable $\mathrm{Cu}$. This may be due to the transformation of $\mathrm{OM}$ in stable form that could link more $\mathrm{Cu}$. In concord to this, Angelova et al. [64] reported that enrichment of soil with $\mathrm{OM}$ could reduce the bioavailable $\mathrm{Cu}$ as a result of complexation of free ions of $\mathrm{Cu}$.

\section{Conclusion}

The study revealed that soils of the study area have limitations related to deficiency of major plant nutrient elements and soil acidity. As a result, most of the soil properties measured responded positively to applications of lime, VC, and chemical P fertilizer either in combination or alone. This incubation experiment demonstrated that the application of lime, VC, and chemical P fertilizer could mitigate soil acidity and $\mathrm{Al}$ toxicity as well as improve soil fertility of acidic soils of the study area. The combined application of medium rates of lime (4 tons.ha $\left.{ }^{-1}\right)$, VC (5 tons $\left.h \mathrm{ha}^{-1}\right)$, and chemical P $\left(40 \mathrm{~kg} \cdot \mathrm{ha}^{-1}\right.$ ) holds a lot of promise as an efficient alternative to amend soil acidity and increase soil nutrient availability. However, the results need to be confirmed under field conditions, and the economic feasibility of application of a particular combination needs to be quantified. Therefore, further field work is recommended to verify this result.

\section{Conflicts of Interest}

The authors declare that they have no conflicts of interest.

\section{Acknowledgments}

This work was supported by the Haramaya University research site (rare greenhouse), Haramaya University Central Laboratory, and Ethiopian Ministry of Education. The authors acknowledge these institutions and staff members of Haramaya University Central Laboratory particularly Mr. Bane Kebede and staff members of greenhouse and the Nekemte Soil Research Center for providing them the necessary support to conduct this study.

\section{References}

[1] P. Van Streaten, Agro Geology: the Use of Rocks for Crops, Enviroquest Ltd., Cambridge, ON, Canada, 2007. 
[2] S. Kenyanjua, M. L. Ireri, S. Wambua, and S. M. Nandwa, "Acid soils in Kenya: constraints and remedial options," 2002. KARI Technical Note No. 11.

[3] P. O. Kisinyo, Constraints of soil acidity and nutrient depeletion on maize (Zea mays L.) production in Kenya, Ph.D. thesis, Moi University, Eldoret, Kenya, Ph.D. thesis, 2011.

[4] P. A. Opala, P. O. Kisinyo, and R. O. Nyambati, "Effects of Tithonia diversifolia, farmyard manure, urea and phosphate fertilizer application methods on maize yields in western Kenya," Journal of Agriculture of Rural Develoment of Tropics and Subtropics, vol. 116, no. 1, pp. 1-9, 2015.

[5] H. Schlede, Distribution of acid soils and liming materials in Ethiopia, Ethiopian Institute of Geological Surveys, Ministry of Mines and Energy, Addis Ababa, Ethiopia, 1989.

[6] World Bank, Staff Appraisal Report. National Fertilizer Sector Project, Ethiopia, 1995, Report No. 13722-ET.

[7] W. Haile and S. Boke, Mitigation of Soil Acidity and Fertility Decline Challenges for Sustainable Livelihood Improvement: Research Findings from Southern Region of Ethiopia and Its Policy Implications, Awassa Agricultural Research Institute, Awassa, Ethiopia, 2009.

[8] M. Abebe, The Nature and Management of Acid Soils in Ethiopia, Addis Ababa, Ethiopia, 2007.

[9] V. Viterello, F. Capadi, and V. Stefanuto, "Recent advances in $\mathrm{Al}$ and resentance in higher plants," Brazil Plant Physiology, vol. 17, no. 1, pp. 129-143, 2005.

[10] E. Ouma, D. Ligeyo, T. Matonyei et al., "Enhancing maize grain yield in acid soils of Western Kenya using Al tolerant germplasm," Journal of Agricultural Science and Technology, vol. 3, pp. 33-46, 2013.

[11] C. The, H. Calba, C. Zonkeng, E. M. Ngonkeu, and V. O. Adetimirin, "Response of maize grain yield to changes in acid soil characterstics after soil amendment," Plant Soil, vol. 284, pp. 45-57, 2006.

[12] M. K. Yao, P. K. Angui, S. Konaté et al., "Effects of land use types on soil organic carbon and nitrogen dynamics in midwest Côte d'Ivoire," European Journal of Science and Research, vol. 40, pp. 211-222, 2010.

[13] N. Z. Lupwayi and I. Haque, "Phosphorous: a prerequisite for increased productivity of forage and browse/free legumes in the Ethiopian highlands," in Proceedings of the Second Conference of the Ethiopian Society of Soil Science, Addis Ababa, Ethiopia, September 1993.

[14] S. Boke, "Soil phosphorous fractions influenced by different cropping system in Andosols and Nitisols in KambataTenbaro and Wolaita Zones, SNNPRS, Ethiopia," Alemaya University, Haramaya, Ethiopia, M.Sc. thesis, 2004.

[15] P. O. Kisinyo, C. O. Othieno, S. O. Gudu et al., "Immediate and residual effects of lime and phosphorus fertilizer on soil acidity and maize production in western Kenya," Experimental agriculture, vol. 50, no. 1, pp. 128-143, 2014.

[16] A. Melese, Y. Markku, and B. Yitaferu, "Effects of lime, wood ash, manure and mineral $P$ fertilizer rates on acidity related chemical properties and growth and $\mathrm{P}$ uptake of wheat (Triticum aestivum L.) on acid soil of Farta district, Northwestern Highlands of Ethiopia," International Journal of Agriculture and Crop Sciences, vol. 8, no. 2, pp. 256-269, 2015.

[17] D. Mengesha and L. Mekonnen, "Integrated agronomic crop managements to improve teff productivity under terminal drought," in Water Stress, I. Md, M. Rahman, and H. Hasegawa, Eds., pp. 235-254, Intech Open Science, London, UK, 2012.

[18] N. Q. Arancon, C. A. Edwards, R. Atiyeh, and J. D. Metzger, "Effects of vermicompost produced from food waste on the growth and yields of greenhouse peppers," Bio-Resources Technology, vol. 93, no. 2, pp. 139-144, 2004.

[19] J. Dominguez, "State of the art and new perspectives on vermicomposting research," in Earthworm Ecology, C. A. Edwardspp. 401-424, CRC Press, Boca Raton, FL, USA, 2nd edition, 2004.

[20] R. M. Azarmi, T. Giglou, and R. D. Taleshmikail, "Influence of vermicompost on soil chemical and physical properties in tomato (Lycopersicum esculentum) field," African Journal of Bio-technology, vol. 7, pp. 2397-2401, 2008.

[21] L. Angin, E. L. Aksakal, T. Oztas, and A. Hanay, "Effects of municipal solid waste compost (MSWC) application on certain physical properties of soils subjected to freeze-thaw," Soil Tillage Research, vol. 130, pp. 58-61, 2013.

[22] J. Lordan, M. Pascual, and F. Fonseca, "Use of rice husk to enhance peach tree performance in soil switch limiting physical properties," Soil Tillage and Research, vol. 129, pp. 19-22, 2013.

[23] R. Abafita, "Evaluation of vermicompost on maize productivity and determine optimum rate for maize production," World Journal of Biology and Medical Sciences, vol. 3, no. 1, pp. 9-22, 2016.

[24] M. R. Haj Seyed Hadi, M. T. Darzi, Z. Ghandehari, and G. H. Riazi, "Effects of vermicompost and amino acids on the flower yield and essential oil production from Matricaria chamomilla L. J. of Med," Plants Research, vol. 5, no. 23, pp. 5611-5617, 2011.

[25] S. Suthar, "Effect of vermicompost and inorganic fertilizer on wheat (Triticum aestivum) production," Nature, Environmental Pollution Technology, vol. 5, pp. 197-201, 2006.

[26] S. I. Glenda, B. Ismet, K. Skender, and B. Astrit, "The influence of vermicompost on plant growth characteristics of cucumber (Cucumis sativus L.) seedlings under saline conditions," Journal of Food, Agriculture and Environmental, vol. 7, pp. 869-872, 2009.

[27] R. K. Sinha, S. Agarwal, K. Chaudhan, and D. Valani, "The wonders of earthworms and its vermicomposting in farm production: Charles Darwin's friends of farmers', with potential to replace destructive chemical fertilizers from agriculture," Agricultural Science, vol. 1, no. 2, pp. 76-94, 2010.

[28] A. Mahajan, R. M. Bhagat, and R. D. Gupta, "Integrated nutrient management in sustainable rice-wheat cropping system for food security in India," SAARC Journal of Agriculture, vol. 6, no. 2, pp. 29-32, 2008.

[29] R. Singh and S. K. Agarwal, "Growth and yield of wheat (Triticum aestivum L.) as influenced by levels of farmyard manure and nitrogen," Indian Journal of Agronomy, vol. 46, no. 3, pp. 462-467, 2001.

[30] G. Angachew, "Ameliorating effects of organic and inorganic fertilizers on crop productivity and soil properties on reddishbrown soils," in Proceedings of the 10th Conference of the Ethiopian Society of Soil Science, pp. 127-150, Addis Ababa, Ethiopia, March 2009.

[31] A. F. Gafar, M. Yassin, D. Ibrahim, and S. O. Yagoob, "Effect of different (bio organic and inorganic) fertilizers on some yield components of rice (Oryza sativa L.)," Universal Journal of Agricultural Research, vol. 2, no. 2, pp. 67-70, 2014.

[32] A. Chimdi, H. Gebrekidan, K. Kibret, and A. Tadesse, "Effects of liming on acidity-related chemical properties of soils of different land use systems in Western Oromia, Ethiopia," World Journal of Agricultural Science, vol. 8, no. 6, pp. 560567, 2012.

[33] A. Kidanemariam, "Soil acidity characterization and effects of liming and chemical fertilization on dry matter yield and 
nutrient uptake of wheat (Triticum aestivum L.) on soils of Tsegede District, Northern Ethiopia," Ph.D. thesis, Haramaya University, Haramaya, Ethiopia, Ph.D. thesis, 2013.

[34] B. Teshome, "Effect of compost, lime and P on selected properties of acidic soils of Asosa," Journal of Biology, Agriculture and Healthcare, vol. 7, no. 5, pp. 2224-3208, 2017.

[35] A. Abraham, Studied Rock Units of Western Ethiopia, Addis Ababa, EthiopiaGeological Survey Bulletin Note No. 305, 1990.

[36] FAO (Food and Agriculture Organization of the United Nations), Edited by P. Driessen, J. Deckers, and F. Nachtergaele, Eds., Food and Agricultural Organizations, Rome, Italy, 2001.

[37] M. Abebe, Natures and Management of Ethiopian Soils, Alemaya University of Agriculture, Haramaya, Ethiopia, 1998.

[38] FAO (Food and Agriculture Organization of the United Nations), Soil Map of the World: Revised Legend, World Soil Resource Report 60, FAO, Rome, Italy, 1990.

[39] NMA (National Meteorological Agency), Gida Ayana Weather Station Rainfall and Temperature Data, NMA, Asosa, Ethiopia, 2015.

[40] G. H. Bouyoucos, "A recalibration of the hydrometer for making mechanical analysis of soils," Agricultural Journals, vol. 43, pp. 434-438, 1951.

[41] V. C. Jamison, H. H. Weaver, and I. F. Reed, "A hammerdriven soil core sampler,” Soil Science, vol. 69, pp. 487-496, 1950.

[42] T. C. Barauah and H. P. Barthakulh, A Text Book of Soil Analysis, Vikas Publishing House, New Delhi, India, 1997.

[43] S. H. Chopra and J. S. Kanwar, Analytical Agricultural Chemistry, Kalyani Publisher, Bengaluru, India, 1976.

[44] D. L. Rowell, Method and Applications, Addison Wesley Longman Limited, London, UK, 1994.

[45] A. Walkley and I. A. Black, "An examination of the Degtjareff method for determining soil organic matter and proposed modification of the titration method," Soil Science, vol. 37, pp. 29-38, 1934.

[46] J. M. Bremner and C. S. Mulvaney, "Nitrogen-total," in Methods of Soil Analysis, Part 2, Chemical and Microbiological Properties, A. L. Page, R. H. Miller, and D. R. Keeneypp. 595-624, American Society of Agronomy, Madison, WI, USA, 2nd edition, 1982.

[47] H. R. Bray and L. T. Kurtz, "Determination of organic and available forms of phosphorus in soils," Soil Science, vol. 59, no. 1, pp. 39-46, 1945.

[48] H. D. Chapman, "Cation exchange capacity by ammonium saturation," in Methods of Soil Analysis, Agronomy Part II, No. 9, C.A. Black, Ed., pp. 891-901, American Society of Agronomy, Madison, WI, USA, 1965.

[49] M. Pansu and J. Gautheyrou, Handbook of Soil Analysis, Springer, New York, NY, USA, 2006.

[50] S. Sertsu and T. Bekele, "Procedures for soil and plant analysis," National Soil Research Center, Ethiopian Agricultural Research Organization (EARO), Addis Ababa, Ethiopia, Technical paper 74, 2000.

[51] C. Pisa and M. Wuta, "Evaluation of composting performance of mixtures of chicken blood and maize stover in Harare, Zimbabwe," International Journal of Recycling of Organic Waste in Agriculture, vol. 2, no. 1, pp. 1-11, 2013.

[52] P. M. Ndegwa and S. A. Thompson, "Integrating composting and vermicomposting in the treatment and bioconversion of solids," Bioresource Technology, vol. 76, pp. 107-112, 2001.

[53] J. R. Okalebo, K. W. Guthua, and P. J. Woomer, Laboratory Methods of Soil and Plant Analysis a Working Manual, TSBFCIAT and SACRED Africa, Nairobi, Kenya, 2002.
[54] A. D. Manson and V. Katusic, Potato Fertilization in Kwazulu-Natal, Cedara Report No.N/A/97/24, Cedara Reports and Publications, 1997.

[55] M. P. W. Farina and P. Chanon, "A field comparison of lime requirement indices for maize," Plant and Soil, vol. 134, pp. 127-135, 1991.

[56] SAS (Statistical Analysis System), SAS/STAT User's Guide, Proprietary Software Version 9.2, SAS Inst., Inc., Cary, NC, USA, 2004.

[57] J. B. Jones, Agronomic Handbook: Management of Crops, Soils, and Their Fertility, CRC Press LLC, Boca Raton, FL, USA, 2003.

[58] T. Tadese, "Soil, plant, water, fertilizer, animal manure and compost analysis," International Livestock Research center for Africa, Addis Ababa, Ethiopia, Working document No. 13, 1991.

[59] B. Clements and I. McGowen, Strategic Fertilizer Use on Pastures: NSW Agriculture, Agnote Reg. 4/57, Orange, NSW, Australia, 1994.

[60] FAO (Food and Agriculture Organization of the United Nations), World Reference Base for Soil Resources: A Framework for International Classification, Correlation and Communication, World Soil Resources Reports No. 103, 2nd edition, 2006.

[61] M. N. Wael, V. R. Leon, C. Sarina, and B. Oswald, "Effect of vermicompost on soil and plant properties of coal spoil in the Lusatian region (Eastern Germany)," Karl-Liebknecht Strasse, vol. 24-25, p. 14476, 2011.

[62] K. Asciutto, M. C. Rivera, E. R. Wright, D. Morisigue, and M. V. López, "Effect of vermicompost on the growth and health of Impatiens wallerana," International Journal of Experimental Botany, vol. 75, pp. 115-123, 2006.

[63] P. O. Kisinyo, S. O. Gudu, C. O. Othieno et al., "Effects of lime, phosphorus and Rhizobia on Sesbania sesban performance in a Western Kenyan acid soil," African Journal of Agricultural Research, vol. 7, no. 18, pp. 2800-2809, 2012.

[64] V. R. Angelova, V. I. Akova, N. S. Artinova, and K. I. Ivanov, "The effect of organic amendments on soil chemical characteristics," Bulgarian Journal of Agricultural Science, vol. 19, no. 5, pp. 958-971, 2013.

[65] P. A. Opala, J. R. Okalebo, and C. O. Othieno, "Effects of organic and inorganic materials on soil acidity and phosphorus availability in a soil incubation study," International Scholarly Research Network Agronomy, vol. 2012, article 597216, 10 pages, 2012.

[66] A. A. Amba, E. B. Agbo, N. Voncir, and M. O. Oyawoye, "Effect of phosphorus fertilizer on some soil chemical properties and nitrogen fixation of legumes at Bauchi," Continental Journal of Agricultural Science, vol. 5, no. 1, pp. 39-44, 2011.

[67] E. O. Adeleye, L. S. Ayeni, and S. O. Ojeniyi, "Effect of poultry manure on soil physicochemical properties, leaf nutrient contents and yield of Yam (Dioscorea rotundata) on Alfisol in Southwestern Nigeria," Journal of American Science, vol. 6, no. 10 , pp. 871-878, 2010.

[68] A. Efthimiadou, D. Bilalis, A. Karkanis, and B. Froud-Williams, "Combined organic/inorganic fertilization enhance soil quality and increased yield, photosynthesis and sustainability of sweet maize crop," Australian Journal of Crop Science, vol. 4, no. 9, pp. 722-729, 2010.

[69] D. D. Mary and S. Sivagami, "Effect of individual and combined application of bio-fertilisers, vermicompost and inorganic fertilizers on soil enzymes and minerals during the post harvesting stage of chilli," Research Journal of Agriculture and Environmental Management, vol. 3, pp. 434-441, 2014. 
[70] M. O. Anetor and E. A. Akinrinde, "Response of soybean [Glycine max (L.) Merrill] to lime and phosphorus fertilizer treatments on an acidic Alfisol of Nigeria," Pakistan Journal of Nutrition, vol. 5, no. 3, pp. 286-293, 2006.

[71] P. O. Kisinyo, "Maize response to organic and inorganic soil amendments grown under tropical acidic soil of Kenya," Journal of Agricultural Science and Food Technology, vol. 2, no. 3, pp. 35-40, 2016.

[72] P. A. Opala, J. R. Okalebo, C. O. Othieno, and P. Kisinyo, "Effects of organic and inorganic phosphorus sources on maize yields in acid soils of western Kenya," Nutrient Cycling in Agroecosystems, vol. 86, pp. 317-329, 2010.

[73] A. Hassan, A. Mohamad, A. Abdu, R. M. Idrus, and N. A. Besar, "Soil properties under Orthosiphon stamineus (Benth) intercropped with Durio zibethinus (Murr) and treated with various organic fertilizers," in Proceedings of the 19th World Congress of Soil Science, Soil Solutions for a Changing World, Brisbane, Australia, August 2010.

[74] R. Repsiene and R. Skuodiene, "The influence of liming and organic fertilization on the changes of some agrochemical indicators and their relationship with crop weed incidence," Zemdirbyste Agriculture, vol. 97, no. 4, pp. 3-14, 2010.

[75] L. Andric, M. Rastija, T. Teklic, and V. Kovacevic, "Response of maize and soybeans to liming," Turkish Journal of Agriculture and Forestry, vol. 36, pp. 415-420, 2012.

[76] L. S. Ayeni and M. T. Adetunji, "Integrated application of poultry manure and mineral fertilizer on soil chemical properties, nutrient uptake, yields and growth components of maize," Nature and Science, vol. 8, no. 1, pp. 60-67, 2010.

[77] O. N. Adeniyan, A. O. Ojo, O. A. Akinbode, and J. A. Adediran, "Comparative study of different organic manures and NPK fertilizer for improvement of soil chemical properties and dry matter yield of maize in two different soils," Journal of Soil Science and Environmental Management, vol. 2, no. 1, pp. 9-13, 2011.

[78] D. C. Edmeades, "Effects of lime on effective cation exchange capacity and exchangeable cations on a range of New Zealand soils," New Zealand Journal of Agricultural Research, vol. 25, no. 1, pp. 27-33, 2012.

[79] C. Pandey and S. Shukla, "Effects of composted yard waste on water movement in sandy soil," Compost Science and Utilization, vol. 14, no. 4, pp. 252-259, 2006.

[80] R. Imerb, N. Bamroongrugsa, K. Kawashima, T. Amano, and S. Kato, "Utilization of coal ash to improve acid soil," Songklanakarin Journal of Science and Technology, vol. 26, no. 5, pp. 697-708, 2004.

[81] D. J. Walker, R. Clemente, A. Roig, and M. P. Bernal, "The effects of soil amendments on heavy metal bioavailability in two contaminated Mediterranean soils," Environmental Pollution, vol. 122, pp. 303-312, 2003. 

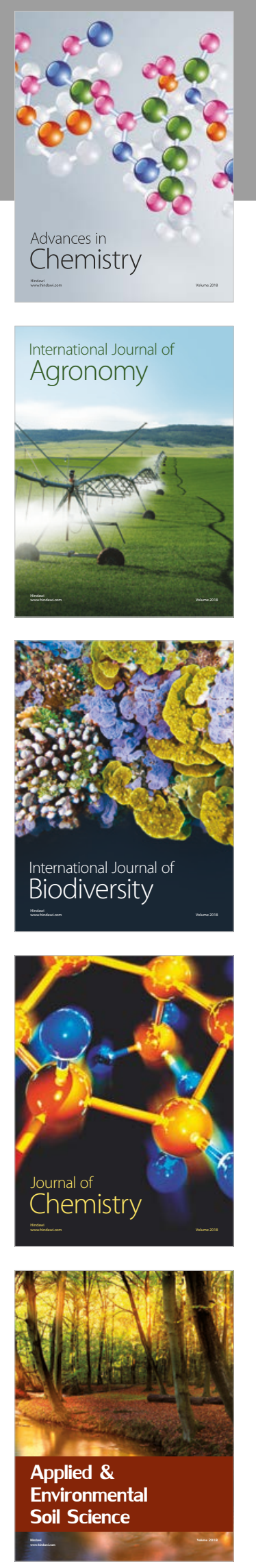

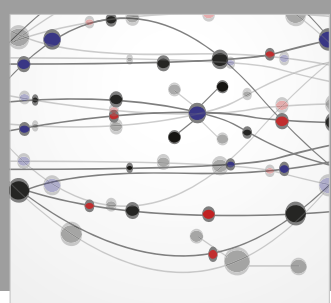

The Scientific World Journal

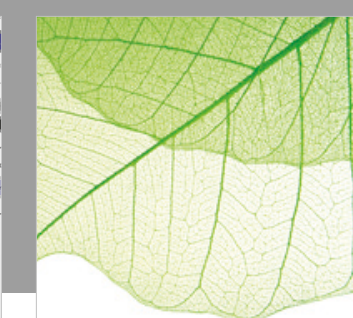

Journal of Botany

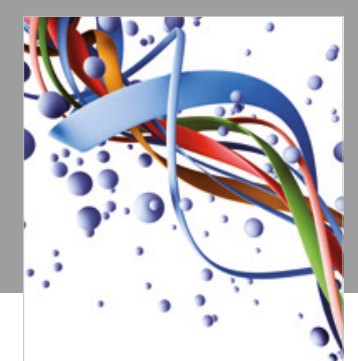

Scientifica

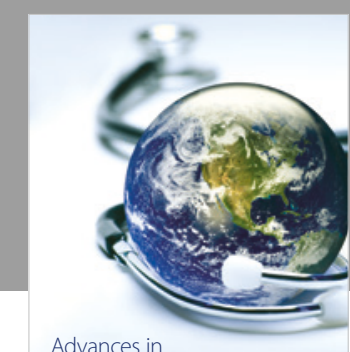

Public Health

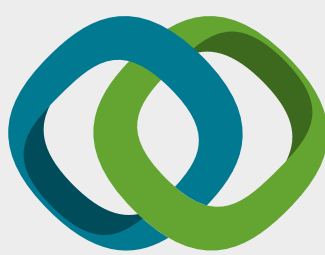

Hindawi

Submit your manuscripts at

www.hindawi.com
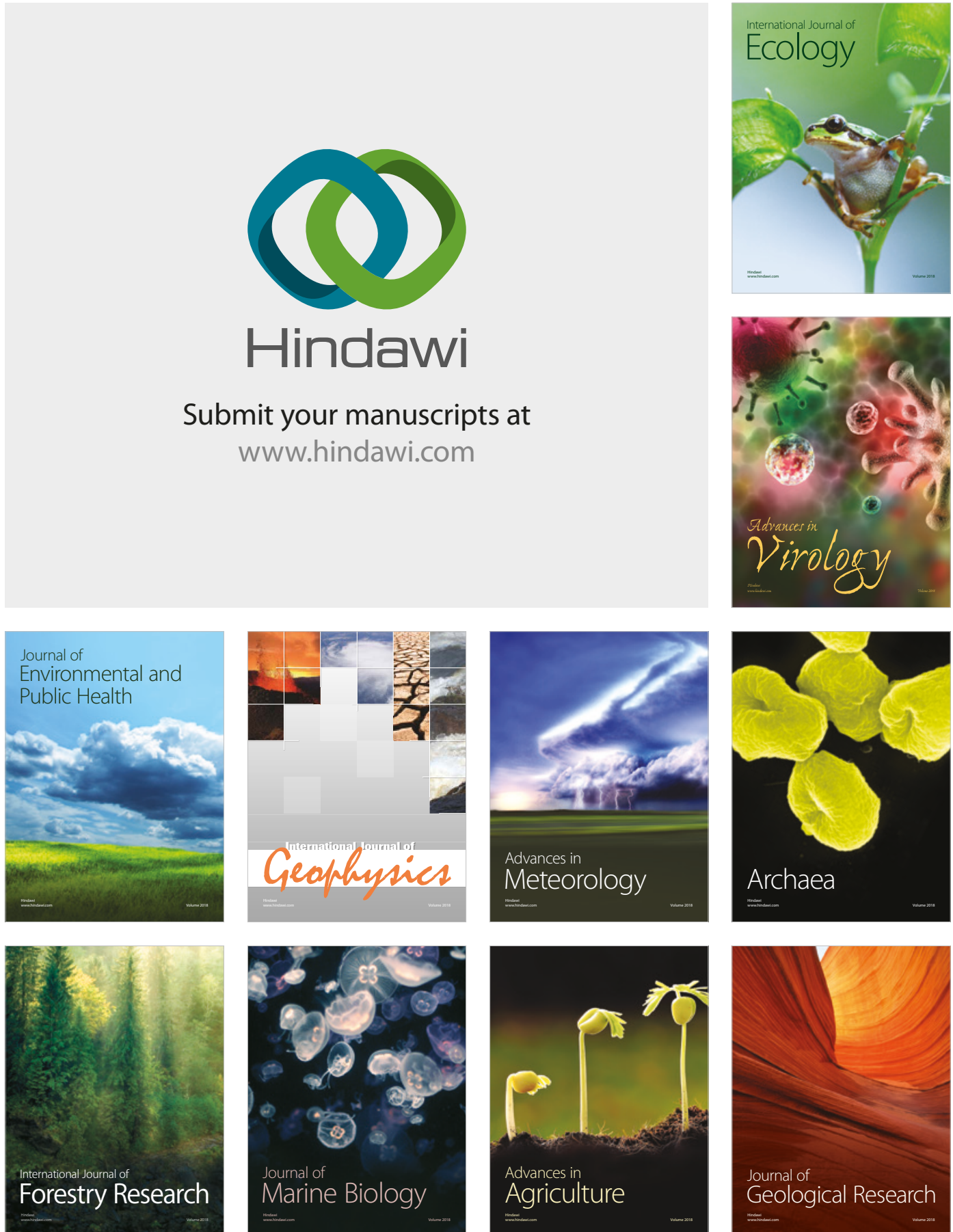

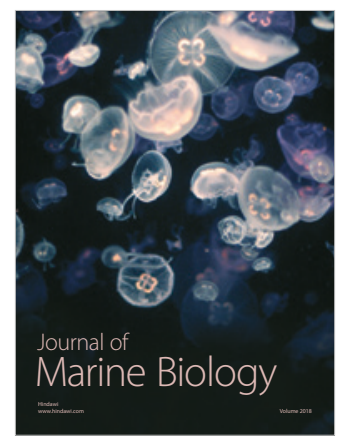

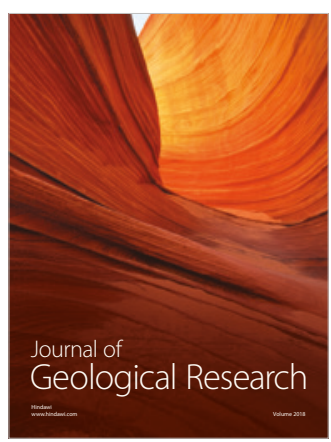

